\title{
Credit Scoring and the Availability, Price, and Risk of Small Business Credit
}

\author{
Allen N. Berger \\ Board of Governors of the Federal Reserve System \\ Washington, DC 20551 U.S.A. \\ Wharton Financial Institutions Center \\ Philadelphia, PA 19104 U.S.A. \\ aberger@frb.gov \\ W. Scott Frame \\ Federal Reserve Bank of Atlanta \\ Atlanta, GA 30303 U.S.A. \\ scott.frame@atl.frb.org \\ Nathan H. Miller \\ Board of Governors of the Federal Reserve System \\ Washington, DC 20551 U.S.A. \\ nmiller@frb.gov
}

April 2002

\begin{abstract}
$\underline{\text { Abstract }}$
We examine the economic effects of small business credit scoring (SBCS) and find that it is associated with expanded quantities, higher average prices, and greater risk levels for small business credits under $\$ 100,000$. These findings are consistent with a net increase in lending to relatively risky "marginal borrowers" that would otherwise not receive credit, but pay relatively high prices when they are funded. We also find that: 1) bank-specific and industrywide learning curves are important; 2) SBCS effects differ for banks that adhere to "rules" versus "discretion" in using the technology; and 3) SBCS effects differ for slightly larger credits.
\end{abstract}

JEL Classification Numbers: G21, G28, G34, L23

Keywords: Banks, Credit Scoring, Small Business, Risk

The views expressed in this paper do not necessarily reflect those of the Federal Reserve Board, Federal Reserve Bank of Atlanta, or their staffs. The authors thank Bob Avery, Chris Cornwell, Bob Eisenbeis, Jill Richardson, Greg Udell, Larry Wall, Cordell Weiss, and seminar participants at the University of Georgia and the 2001 Credit Scoring and Credit Control meetings in Edinburgh, Scotland for helpful comments and suggestions.

Please address correspondence to Allen N. Berger, Mail Stop 153, Federal Reserve Board, 20th and C Streets. NW, Washington, DC 20551, call 202-452-2903, fax 202-452-5295, or email aberger@ frb.gov. 


\section{Credit Scoring and the Availability, Price, and Risk of Small Business Credit}

\section{Introduction}

Advances in information processing, telecommunications, and financial engineering have been integral parts of the transformation of the U.S. commercial banking industry in recent years. This paper focuses on one rapidly spreading technology that embodies these advances - small business credit scoring (SBCS). Specifically, we examine how the adoption of SBCS affects the availability, price, and risk of small business credit.

Our analytical framework provides an intuition for how the adoption of SBCS may change the way banks process information and make credit decisions about small business loan applicants. We show how SBCS may act as a substitute for or complement to other lending technologies, and may result in reduced lending costs, improved accuracy in evaluating creditworthiness, or both. In addition, we indicate how the adoption of SBCS may result in either expanded or contracted availability of credit, higher or lower average prices for credit, and greater or lesser credit risk for different pools of small business loan applicants. Importantly, the framework provides a number of testable predictions for our empirical models.

We estimate the effects of SBCS on the availability, price, and risk of credit for the years 19951997 using data from a survey of large U.S. banks on whether and how they use SBCS. We measure the extent to which institutions rely more on "rules" - automated decisions for approval/rejection and prices based on externally produced credit scores - versus "discretion" - banks developing their own scoring models and using other inputs in credit decisions. The scoring information is combined with data on the sample banks' individual small business loan prices, risk ratings, and other contract terms from the Federal Reserve's Survey of Terms of Bank Lending. We also match these data with Call Report and Summary of Deposits data on the sample banks and other banks operating in their local markets.

By way of preview, the data suggest that the adoption of credit scoring is associated with expanded quantities, higher average prices, and greater risk for small business credits under $\$ 100,000$. These findings are consistent with the hypothesis that a dominant effect of SBCS is a reduction in lending costs and/or improved accuracy of credit assessments that allows banks to expand credit to some 
relatively risky "marginal borrowers" that would otherwise not receive credit. These borrowers tend to pay relatively high prices when they are funded because of higher risks, more informational opacity, or other associated additional costs of processing their loans. Other results include that: 1) both bankspecific and industrywide learning curves are important; 2) the effects of SBCS differ according to the extent to which the bank adheres to "rules" versus "discretion" in using the technology, and 3) the effects of SBCS differ for slightly larger credits (between $\$ 100,000$ and $\$ 250,000$ ).

The findings of this research may have a number of important implications. For example, there is an on-going concern that the consolidation of the banking industry may result in less credit available to some small businesses. Our results suggest that this effect may be offset to some degree by SBCS, a technology that appears to allow large banks to expand their small business lending to some "marginal borrowers" that would not otherwise receive credit.

The paper proceeds as follows. Section II provides background information on SBCS and the related literature. Section III outlines our analytical framework. Section IV discusses the data sources. Section V describes the variables, gives some sample statistics, and shows our empirical models. Section VI presents the empirical results, and Section VII concludes.

\section{Small Business Credit Scoring and Related Literature}

SBCS is a relatively new technology for lending to informationally opaque small businesses that involves processing data about the firm and its owner using statistical methods. ${ }^{1}$ The outcome is a score, or summary statistic about the borrower's expected future loan performance (Feldman 1997, Mester 1997). Although credit scores have been used for some time in the underwriting of consumer loans, this technology has only recently been applied to small commercial credits, which had been thought to have nonstandardized documentation and to be too heterogeneous (Rutherford 1994/1995). However, credit analysts ultimately determined that the personal credit history of small business owners is highly predictive of the loan repayment prospects of the business. ${ }^{2}$ The personal information used in SBCS

\footnotetext{
${ }^{1}$ See Hand and Henley (1997) for a review of the statistical methods used for consumer credit scoring. See Avery, Bostic, Calem, and Canner (2000) for a discussion of statistical issues, such as omitted variable bias, that may affect the accuracy of credit scoring models.

${ }^{2}$ Similar statistical techniques, such as discriminant analysis, are also used in lending to larger businesses but these
} 
models may include the owner's monthly income, outstanding debt, financial assets, employment tenure, home ownership, and previous loan defaults or delinquencies (Mester 1997). The personal information is obtained from one or more consumer credit bureaus and may be combined with data from commercial credit bureaus and basic business-specific data collected by the bank to enter into the prediction model. ${ }^{3}$ In the long run, the use of SBCS may help in the development of a secondary market for pools of small business debt, similar to the way in which consumer credit scoring helped in the development of secondary markets for consumer debt.

While some large banks have developed proprietary SBCS models (e.g., Wells Fargo), most have turned to models from outside vendors. The largest provider of external models, Fair, Isaac and Company, introduced its first SBCS model in 1995. The model used a sample of more than 5000 small business loan applications over five years from 17 large U.S. banks designed to represent a national pool of small business loan applicants. ${ }^{4}$ Today, there are alternative external vendors that are typically also in the commercial credit information business (e.g., Dun \& Bradstreet, Experian). SBCS products also vary considerably in the amount and type of information they require and in the way the lender accesses them. For example, the data entered by the lender may be as little as an SIC code and checking account balance all the way up to including extensive financial statement information on the business as well. The credit scores may be accessed through desktop software on a personal computer, via mainframe server, or over the Internet. While these models may be designed for use for credits up to $\$ 250,000$, many lenders use them only for amounts less than $\$ 100,000$. A fee is typically charged for every small business credit score obtained, as opposed to a flat fee for the service.

To our knowledge, the extant evidence on the effects of SBCS on small business credit is limited to two studies. One study estimated that the use of SBCS increased the portfolio share of small business loans under $\$ 100,000$ by 8.4 percentage points for a sample of large commercial banking organizations in 1997 (Frame, Srinivasan, and Woosley 2001). The other study found that in 1997 the use of SBCS by large banks increased small business loans under $\$ 100,000$ in low- and moderate-income census tracts

\footnotetext{
are typically not focused on the personal credit history of the business owners (Saunders 2000).

${ }^{3}$ See Eisenbeis (1996) and Mester (1997) for detailed background information about the introduction of SBCS.

4 This model, which was constructed in cooperation with the Robert Morris Associates, was further refined in 1996 using data from 25 banks.
} 
and that this effect was twice that for higher-income areas (Frame, Padhi, and Woosley 2001).

While we employ the same SBCS survey data used in these two previous studies, this paper makes several significant extensions and contributions. First, we examine the effects of SBCS on the price and risk of small business credits under $\$ 100,000$, as well as the quantity of this credit, providing a more complete picture of how small business borrowers fare from the adoption of SBCS. Second, we test the presence and slope of bank-specific learning curves, or the effects on quantity, price, and risk of the length of time since an individual bank adopted SBCS. Third, we conduct our analysis over a 3-year period and examine the effects of the industrywide learning curve, rather than focusing exclusively on the single year of 1997. Fourth, we examine how the effects of SBCS differ with the extent to which banks adhere to "rules" versus "discretion" in using the technology. Finally, we investigate how the effects of SBCS differ for slightly larger credits between $\$ 100,000$ and $\$ 250,000$.

Recent research is consistent with a view of SBCS as one of several recent innovations for delivering financial services driven by technological improvements. Two studies found that SBCS is more likely to be adopted, or adopted earlier, by larger banking organizations with more branches, but fewer separately chartered banks - consistent with the benefits of spreading the costs of technology adoption over more resources, and with potential organizational diseconomies of using this technology within the holding company form (Akhavein, Frame, and White 2001, Frame, Srinivasan, and Woosley 2001). Studies of other innovations in the banking industry - including Internet banking (e.g., Furst, Lang, and Nolle 2000), automated clearinghouse (e.g., Gowrisankaran and Stavins 1999), and ATMs (e.g., Hannan and McDowell 1984) - in some cases had similar and in some cases had dissimilar findings in terms of the effects of bank size and holding company affiliation on speed of adoption.

Other recent research is consistent with a view of SBCS as one part of an on-going movement to use more quantitative methods in bank small business lending. Some studies found that banks increased the distances at which they lent to small businesses and the use of impersonal methods of contact prior to the widespread implementation of SBCS in the mid-1990s (e.g., Kwast, Starr-McCluer, and Wolken 1997, Petersen and Rajan 2002). Other research found that banks increased their lending to small businesses outside their own local market in the late 1990s, after SBCS became widespread (Cyrnak and Hannan 2000). One study also found that banking organizations have been increasing their control over 
distant affiliates over time, consistent with the use of more quantitative methods such as SBCS, which may require less monitoring of loan officers (Berger and DeYoung 2001). Finally, another study suggested that the latter trend may be drectly linked to SBCS - as its use was found to significantly increase the probability that a large bank will make loans in a given census tract (Frame, Padhi, and Woosley 2001).

The introduction of SBCS and its economic effects are also related to the issue of technological change and productivity growth in the banking industry. Studies of U.S. bank productivity growth during the 1990s often found either productivity declines or only very slight improvements using cost productivity or linear programming methods (e.g., Wheelock and Wilson 1999, Stiroh 2000, Berger and Mester 2001). However, the latter study also found profit productivity to be increasing even while cost productivity declined, especially for large banks. This finding is consistent with he hypothesis that technological progress allowed banks to offer more or better services that may have raised costs, but that customers were willing to pay more for these services, raising revenues by more than the cost increases. A number of technological changes are likely responsible for this finding, possibly including SBCS if it resulted in greater lending to high-cost borrowers that were charged high prices for credit that more than covered their high costs. As shown below, our empirical results are consistent with this possibility.

Finally, the issue of the effect of SBCS on credit availability is intertwined with the issue of the effect of banking industry consolidation on credit availability. A number of studies found that large banks tend to devote lower proportions of their assets to small business lending than smaller institutions and that mergers and acquisitions (M\&As) involving large banking organizations generally reduce small business lending substantially (e.g., Berger, Saunders, Scalise, and Udell 1998). The adoption of SBCS may offset some or all of the reduction in relationship credit by large consolidated banks. The consolidating institutions or other institutions may use the SBCS technology to serve some of the borrowers that might otherwise be dropped, or use this technology to extend credit to other borrowers that might otherwise not receive bank funding.

\section{Analytical Framework}

In this section, we outline a framework for analyzing the economic effects of the adoption of 
SBCS. We first provide some intuition about how the introduction of SBCS may change the way banks process information and make credit decisions. Second, we show how the adoption of SBCS may alter small business credit availability, price, and risk. Third, we discuss the testable implications of this framework for our empirical models.

\section{A. The Effects of the Adoption of SBCS on a Bank's Credit Process}

Our framework begins with a bank that adopts SBCS technology. Prior to adoption, the bank used one or more incumbent lending technologies to evaluate small business credits, such as financial statement lending (based primarily on financial statements), asset-based lending (based primarily on collateral), or relationship lending (based primarily on "soft" or nonquantitative information about the firm and its owner gained through contact over time). ${ }^{5}$ SBCS may substitute for one or more of these other technologies in gathering information and making decisions for various potential borrowers. The bank may also use SBCS as a complement to another lending technology by employing the credit scores as additional information in implementing that technology.

The adoption of SBCS may result in the discontinuation of an incumbent lending technology by the bank. This could occur if SBCS substitutes for this technology for analyzing a substantial fraction of the loan applicants, perhaps leaving the incumbent technology at below minimum efficient scale. A technology might also be dropped for the purpose of avoiding organizational diseconomies associated with employing too many different technologies together. Relationship lending may be the most likely technology to be discontinued because it differs from SBCS and other transactions-based lending technologies in the use of information ("soft" nonquantitative information versus "hard" quantitative data). SBCS may also tend to substitute for relationship lending because both of these technologies rely heavily on the use of personal information about the firm's owner for informationally opaque firms that do not have strong financial statements.

We assume that on average, the adoption of SBCS decreases lending costs, increases accuracy in evaluating creditworthiness, or both. Presumably, such cost savings and/or more accurate credit evaluations are the reasons for adopting this technology and the reason that banks adopting SBCS tend to keep this technology (i.e., it is an absorbing barrier). It seems unlikely that the adoption of SBCS would

\footnotetext{
${ }^{5}$ See Berger and Udell (2002) for brief descriptions of these lending technologies.
} 
result in any significant, lasting increase in market power, since many other banks generally have access to essentially the same credit scores.

\section{B. The Effects of SBCS Adoption on Small Business Credit Availability, Price, and Risk}

The adoption of SBCS may significantly alter the availability and price of credit to individual small business loan applicants, and change the risk composition of the borrowers that receive credit. Here, we briefly outline the range of possible effects.

For some small business loan applicants, the bank may continue to employ an incumbent technology without the use of credit scores. For these applicants, there should be little or no change in the availability or price of credit unless the implementation of SBCS creates significant organizational problems or draws away significant resources. There may also be loan applicants for which SBCS is used that are denied credit, but would have been denied credit under the incumbent technology as well. Again, there is no significant effect on these firms in terms of price or availability of credit due to the adoption of SBCS.

We divide the remaining firms - those that may be affected by the adoption of SBCS into two categories - 1) "nonmarginal borrowers" or firms that would be approved for credit whether or not SBCS is adopted; and 2) "marginal borrowers," or firms that gain or lose access to credit as a result of the adoption of SBCS. Under SBCS, some "nonmarginal borrowers" may pay lower prices for credit or face other contract terms that are less restrictive (e.g., reduced collateral requirements, larger credit lines, etc.) for at least three possible reasons. First, if the overall costs of lending to a firm (including due diligence, on-going monitoring, etc.) decrease, some of these cost savings may be passed on to the firm as lower interest rates. Second, if the use of SBCS improves the bank's accuracy in evaluating the creditworthiness of some types of firms, then the price or other terms may also become more favorable because of reduced moral hazard or adverse selection problems. The improved accuracy may allow the bank to eliminate some of the worst borrowers in their applicant pool (adverse selection) or to reduce the ability of borrowers to take on more risks after the loan is granted (moral hazard). Third, irrespective of any change in costs or accuracy, some firms may pay lower prices because they are evaluated as higher quality when SBCS is used. ${ }^{6}$ That is, for some firms, the "new" information set that includes credit

\footnotetext{
${ }^{6}$ That is, for some firms, the "new" information set that includes a credit score may suggest that these firms are less
} 
scoring information may suggest that these firms are less risky than the "old" information set.

Other "nonmarginal borrowers" may pay higher prices as a result of the adoption of SBCS because the converse of these conditions may hold. That is, lending terms may worsen because bank costs could increase, accuracy could decrease, or the "new" information set may suggest more risk than the "old" set for these borrowers. ${ }^{7}$ Although all of these effects may occur to some degree across different banks and different borrowers, it seems most likely that there would be a net reduction in average prices for "nonmarginal borrowers" due to the overall improvements in lending costs and/or accuracy discussed above.

Some "marginal borrowers" may gain access to credit for essentially the same reasons given above. First, any cost savings from the use of SBCS may transform some loans from negative net present value (NPV) investments into positive NPV investments and let the bank expand its lending reach into some pools of firms that were previously unprofitable to serve. Second, improved accuracy may allow the bank to expand its lending into pools of firms that were previously too informationally opaque to be creditworthy. That is, the adoption of SBCS may reduce moral hazard and/or adverse selection problems to the point where some loans are positive NPV rather than negative NPV investments. Third, irrespective of any change in costs or accuracy, some "marginal borrowers" may gain access to credit using SBCS because these firms are evaluated as higher quality credits. Loans to these firms may be positive NPV investments using the "new" information, whereas these loans were negative NPV investments using the "old" information.

The use of SBCS may cause other "marginal borrowers" that would otherwise be granted credit to lose access to credit because 1) the costs of lending increase, 2) the bank's accuracy decreases, or 3) the "new" information set is less favorable than the "old" information set. Note that by assumption above, either (1) or (2) may be true, but they cannot both hold, since SBCS would not be adopted and kept if both raised costs and was less accurate.

Other "marginal borrowers" may also lose access to credit because the adoption of SBCS causes the bank to discontinue a lending technology under which these borrowers' loans would be evaluated as

risky than the "old" information set, and the bank may respond with easier credit terms.

${ }^{7}$ Note that all these types of price and contract term changes may also occur if firms are switched from one incumbent lending technology to another because one of these technologies is discontinued. 
positive NPV investments to a technology under which these loans are negative NPV investments. Note, however, that if "marginal borrowers" lose their access to credit, there may be "external effects," or general equilibrium effects, in which other banks react and pick up some of these borrowers. Similar effects have been found for the effects of bank consolidation (e.g., Berger, Saunders, Scalise, and Udell 1998). For example, if the firm is denied credit because the bank discontinued a technology under which the firm's loan is a positive NPV investment, then another bank that continues to use that technology may pick up the loan.

"Marginal borrowers" do not face price increases or decreases from the bank adopting SBCS, since these firms simply either gain or lose access to credit (although they may pay a higher or lower price at another bank). Nonetheless, the addition to or subtraction of these firms from the pool of firms receiving loan contracts from the adopting bank may have important effects on the average price paid for credit at that bank. We assume that "marginal borrowers" pay higher loan prices on average than "nonmarginal borrowers" because they generally have higher credit risk, greater informational opacity, and/or are more costly to serve than other borrowers that are not at the margin of acceptance/denial.

\section{Testable Implications of the Framework for Our Empirical Models}

The analytical framework provides some testable implications for the effect of SBCS on the availability, price, and risk of credit. Our empirical models below compare the predicted quantities, prices, and risk ratings of small business credits for banks that did and did not adopt SBCS, controlling for other exogenous differences among the banks and their markets. The arguments above suggest that the adoption of SBCS is likely to have mixed effects on small business loan applicants - some are likely to face virtually no change in credit availability or terms, whereas some will likely gain or lose access to credit, and others will likely face higher or lower prices. The credit risks of the borrowers receiving credit may also change significantly as "marginal borrowers" are added and subtracted.

The framework also suggests which of these effects are likely to dominate for different pools of small businesses. Specifically, it suggests that credit prices are likely to be lower on average for "nonmarginal borrowers" at banks that have adopted SBCS relative to banks that have not adopted this technology. This is due to reduced bank lending costs and/or improved bank accuracy. The framework does not predict whether more "marginal borrowers" will gain versus lose access to credit, but it does 
predict that if there is a net gain (loss) of these firms, this will tend to increase (decrease) the average prices and credit risks at the bank because of the relatively high prices paid by "marginal borrowers" and the relatively high credit risk of these firms when they receive credit. We note the effects averaged across all borrowers, because we cannot identify the "nonmarginal borrowers" from the "marginal borrowers" in the empirical application.

Based on the analytical framework, an empirical finding of higher lending quantities for banks that have adopted SBCS versus those that have not adopted this technology may be attributed to a net increase in lending to "marginal borrowers." That is, higher lending quantities imply that more firms receive credit that would otherwise be denied than firms that are denied that would otherwise be accepted. Conversely, a finding of lower lending quantities for SBCS banks may be attributed to a net decrease in lending to "marginal borrowers." A finding of no significant change in lending quantities would imply that approximately as many "marginal borrowers" are added as are subtracted.

The interpretation of any difference found in the average small business loan prices between banks that have and have not adopted SBCS depends in a critical way on the finding for the effects of the adoption of SBCS on lending quantities. If lending quantities are higher on average for SBCS banks, then an additional finding of higher average small business loan prices for banks that have adopted SBCS may be attributed to an empirical dominance of 1) the relatively high prices paid by the net additional "marginal borrowers" over 2) the net reduction in average prices for "nonmarginal borrowers." This empirical dominance would be reversed for a finding of higher quantities and lower prices for SBCS banks. A finding of higher quantities and no significant differences in average prices of SBCS banks would suggest that the influences on prices of the increase in high-priced "marginal borrowers" and the reduction in average prices paid by "nonmarginal borrowers" are approximately offsetting.

In contrast, if SBCS is associated with lower lending quantities, both of the major effects on prices point toward lower prices. The net reduction in high-priced "marginal borrowers" would tend to reduce the average prices paid for credit, which would complement the lower average prices paid by "nonmarginal borrowers." A finding of lower quantities and equal or higher prices for SBCS banks would be inconsistent with the predictions and would lead us to reject the framework.

The framework also predicts that a net increase (decrease) in lending to "marginal borrowers" 
should increase (decrease) loan credit risks on average, as "marginal borrowers" are likely to have significantly higher credit risks on average than "nonmarginal borrowers." However, the effect of the adoption of SBCS on the credit risks of "nonmarginal borrowers" cannot be predicted ex ante. The average risks on "nonmarginal borrowers" is likely to decline if accuracy is improved and the bank reduces moral hazard and adverse selection problems significantly. Conversely, the average risk on loans to "nonmarginal borrowers" is likely to increase if accuracy suffers significantly as a result of the adoption of SBCS. The overall effects on credit risk will be the net effect of these different influences.

These quantity, price, and risk outcomes may differ at various points along the industrywide or bank-specific learning curves as the banking industry as a whole or individual banks that have adopted SBCS gain more experience with the technology. As examples, at later points on the learning curves, banks may be able to 1) reduce costs more and/or gain greater improvements in accuracy than at earlier points, and/or 2) apply SBCS to expand lending to more "marginal borrowers" than at earlier points. In our empirical model, we test for these changes by estimating the effects on prices and quantities 1,2 , and 3 years after the adoption of SBCS (i.e., bank-specific learning curves), and by evaluating the effects of SBCS for the three years 1995, 1996, and 1997 (i.e., along the industrywide learning curve).

We also test how the outcomes differ with the extent to which banks rely more on "rules" making automated approval and pricing decisions based on externally produced credit scores - versus exercising more "discretion" - using other inputs in credit decisions and developing their own models. Banks that follow SBCS "rules" may be thought of as those that primarily substitute SBCS for other lending technologies - a bank that purchases a score and uses it for automated decisions is essentially using only the SBCS technology for the affected loan applicants. In contrast, banks that use more "discretion" may be thought of as using credit scores as complements to the other technologies, i.e., adding the scores to financial statement, collateral, and/or relationship information.

The tests of the differences in results for banks following "rules" versus exercising "discretion" may also help in distinguishing between the effects of SBCS when it is used to reduce lending costs versus to improve accuracy in evaluating creditworthiness. When banks follow "rules," substituting SBCS for other technologies and putting very little effort into decision making, the purpose is more likely to reduce costs. When banks exercise more "discretion," using the credit scores as additional information 
to complement the use of other technologies, the purpose is more likely to improve accuracy since total cost of lending generally increases.

\section{Data Sources}

The data employed in this study are drawn from several sources. The first is a January 1998 telephone survey conducted by the Federal Reserve Bank of Atlanta, which queried the lead (largest) banks of 190 of the 200 largest U.S. banking organizations on whether and how they used SBCS. ${ }^{8}$ Ninety-nine institutions responded and indicated whether their bank had adopted SBCS and, if so, the date of the adoption. Data were also collected from these banks about the sizes of credits that were scored, whether they purchased scores, and whether the scores were used in automated approval/rejection or pricing decisions.

We also draw data from the Federal Reserve's Survey of Terms of Bank Lending (STBL). The STBL covers approximately 300 U.S. banks per quarter (although the respondent set is not constant over time), and obtains details on the contract terms and risk ratings of all new domestic commercial and industrial (C\&I) loans issued by these banks during one or more days of the first week of the second month of the quarter. The survey oversamples the largest banks, which is helpful for matching with the credit scoring survey. For the years 1995, 1996, and 1997, we are able to match the contract terms of 49, 47, and 56 banks from the STBL that also responded to the SBCS survey. Our analysis of loan risk is restricted to 1997 because the loan risk ratings were first collected in the second quarter of that year. We are also missing risk ratings from some banks that did not maintain internal ratings or failed to convert their internal ratings into the STBL risk rating format.

Finally, we match these SBCS and loan contract data with information on the bank and other banks in its local markets from standard regulatory reports. The June Call Reports provide data on small business loans outstanding as of June 30 of that year by each bank. The data include the outstanding values of C\&I loans to firms with total credit of less than $\$ 100,000$ and to firms with credit of $\$ 100,000$ to $\$ 250,000$, as well as to larger credits for which SBCS is generally not relevant. ${ }^{9}$ The FDIC's Summary

\footnotetext{
${ }^{8}$ Organization size was measured by total domestic banking assets as of June 30, 1997 . The 10 organizations that were eliminated ex ante were not principally engaged in small business lending (less than $0.50 \%$ of banking assets in small business loans) or were credit card banks.

${ }^{9}$ The dollar values for the size categories are in nominal terms and include the total amount of the commitment (if
} 
of Deposits data set gives the location of every branch of every bank and the total deposits in each branch. By combining Call Report and Summary of Deposits data, we are able to compute weighted-average values for local market deposit concentration and the conditions of other banks in the local markets in which each sample bank competes.

Our sample is not fully representative of the banking industry or of those banks that have adopted SBCS. The credit scoring and STBL surveys are both more representative of the largest banks and there may be further nonresponse bias as well. Nonetheless, the data do represent a significant fraction of the small business lending of the banking industry. As of June 30, 1997, the 56 banks that responded to both the SBCS and STBL surveys held $24.5 \%$ of all C\&I loans less than $\$ 100,000$ and $24.3 \%$ of all C\&I loans between $\$ 100,000$ to $\$ 250,000$ within the banking industry.

\section{Variables, Sample Statistics, and Empirical Models}

The analytical framework described above provides some testable implications for the economic effects of SBCS adoption. We specify three sets of cross-sectional regressions to help determine which of the hypothesized effects on loan quantities, prices, and credit risks dominate empirically. The first set examines the effect of SBCS on credit availability, controlling for certain bank and market-specific variables and average loan contract terms. The second set examines the effect of SBCS on the prices of individual loans, controlling for bank and market-specific variables, individual loan contract terms, and seasonal time dummies. The third set examines the effect of SBCS on the credit risk ratings on individual loans, controlling for bank variables, individual loan contract terms, and seasonal time dummies. Our main focus is on small business credits under $\$ 100,000$ using cross section data for 1997 - the most recent year of the data set that reflects the most industry experience with SBCS. We also specify several variants of the model to test additional hypotheses and to act as robustness checks.

\section{A. Variables and Sample Statistics}

Table 1 describes the variables used in the quantity, price, and risk regressions and provides their means and standard deviations over the 1995-1997 period for both small business credits under $\$ 100,000$

any). As is standard procedure in bank lending research, we treat these credits as small business loans, although we cannot rule out the possibility that in some cases these may be small credits to large businesses. 
(100K) and those between $\$ 100,000$ and $\$ 250,000(100 \mathrm{~K}-250 \mathrm{~K})$. For simplicity, all the variables that refer to the smaller credits have a " 1 " suffix, and those that refer to the slightly larger credits have a "2" suffix. While many of the variables used in the different regressions are conceptually identical, they have different sample statistics because the quantity regressions weight each bank equally, while the price and risk regressions weight each loan equally.

The dependent variable for the loan quantity regressions is SBL-RATIO, or the share of gross total assets (GTA) devoted to small business lending by each bank for each loan size category. The sample banks averaged an SBL-RATIO ratio of $1.38 \%$ for credits under $100 \mathrm{~K}$ and $0.88 \%$ for credits of $100 \mathrm{~K}-250 \mathrm{~K}^{10}$

The dependent variable for the price regressions is PREM, the loan rate premium, or the difference between the loan interest rate and the rate on a Treasury security of comparable repayment duration. ${ }^{11}$ Defining the price of the loan as a spread (rather than in levels) allows us to directly account for prevailing credit market conditions. The average loan premium for the credits under $100 \mathrm{~K}$ is $4.50 \%$, or 450 basis points, while the average PREM for the credits of $100 \mathrm{~K}-250 \mathrm{~K}$ is $3.98 \%$.

The dependent variable for the risk regressions is RISK-RATING, which takes a value of 1 if the loan is rated "minimal" risk, 2 if the loan is rated "low" risk, 3 if the loan is rated "moderate" risk, 4 if the loan is rated "acceptable" risk, and 5 if the loan is special mention or a classified asset (usually part of a workout arrangement). The STBL instructions relate the rating of 1 with AA rated corporate bonds and the rating of 2 with $\mathrm{BBB}$ corporate bonds, but it is difficult to provide a bond equivalent for ratings lower than 2. There is a strong bivariate association between risk and loan price, as expected. The average PREM for the five risk values are $0.0271,0.0357,0.0425,0.0434$, and 0.0474 , respectively, for credits under 100K. The qualitative nature of RISK-RATING regressions makes precise quantitative interpretation difficult. Banks may differ in their interpretation of the STBL risk ratings or in their translation of internal ratings into STBL ratings. ${ }^{12}$ Nonetheless, the cross-section of STBL risk ratings

\footnotetext{
10 There is one fewer observation for the slightly larger credits - 151 versus 152 - because one bank in one year reported no loans of $100 \mathrm{~K}-250 \mathrm{~K}$.

${ }^{11}$ We omit all observations for which PREM is less than -0.01 or greater than 0.15 to eliminate observations that may be grossly mismeasured. We assume that PREM fully reflects any effect of SBCS on loan prices, but we acknowledge that there could effects on other fees that we are not able to measure with the STBL data.

${ }^{12}$ For example, internal ratings could measure default probabilities or the expected costs of future losses.
} 
does provide useful qualitative comparisons of the risks. The means and standard deviations for the exogenous variables in the risk regressions differ somewhat from the sample statistics shown in Table 1 for the price regressions because of the smaller sample size (loans for which ratings were reported starting in the second quarter of 1997). ${ }^{13}$

Note that our use of the risk ratings is for the purpose of discovering the effects of SBCS on the small business loans that are issued by the banks engaging in this lending technology, rather than for investigating the effects of SBCS on the overall risk of these institutions. In most cases, the effects of any changes in small business credit risk due to the adoption of SBCS on overall bank risk are likely to be very small, given that small business lending typically constitutes only a very small portion of the portfolio of these large banks.

Our key exogenous variables are those indicating the use of SBCS. The first is ADOPTEDSBCS, a dummy variable indicating whether a bank had adopted SBCS. SBCS had been adopted for $46.05 \%$ and $32.45 \%$ of the bank-year observations for the credits under $100 \mathrm{~K}$ and $100 \mathrm{~K}-250 \mathrm{~K}$, respectively. The corresponding figures are higher for individual loans employed in the price regressions, $63.17 \%$ and $46.87 \%$, respectively, likely because the banks that have adopted SBCS tend to be larger and have more loans represented in the data set.

To account for bank-specific learning curves associated with the technology, we include TIMESINCE, the number of years since the bank adopted SBCS. The sample statistics shown in Table 1 incorporate zeros for banks that have not adopted SBCS, so these figures must be interpreted with care. For example, the 0.7100 in the first column implies that of the $46.05 \%$ of bank-years in which SBCS had been adopted for credits under $100 \mathrm{~K}$, the technology had been employed for 1.542 years on average $(0.7100 / 0.4605)$.

We use three dummy variables to capture the differences between banks that use decision rules based on credit scores - "rules" banks - and those that use the scores as a discretionary input to underwriting decisions - "discretion" banks. BOUGHT indicates whether the bank purchased credit scores from a vendor, SET-TERMS denotes whether the bank used small business credit scores to set loan terms, and AUTO-APPROVE indicates whether the bank used small business credit scoring to

\footnotetext{
${ }^{13}$ For more information on the STBL risk ratings, see Brady, English, and Nelson (1998).
} 
automatically approval or reject loan applicants. Again, the sample statistics shown in Table 1 must be interpreted with care because they incorporate zeros for banks that have not adopted SBCS. The means in the first column of $0.3816,0.1579$, and 0.2434 imply that $82.87 \%, 34.29 \%$, and $52.86 \%$ of the banks that adopted SBCS for credits under 100K had bought the scores, used them to set terms, and used them for automatic approvals/denials, respectively $(0.3816 / 0.4605,0.1579 / 0.4605$, and $0.2434 / 0.4605)$. It is notable that for credits of $100 \mathrm{~K}-250 \mathrm{~K}$, approval/denial decisions are much less often automated.

As shown next in Table 1, we control for certain bank and local market variables. To account for bank size, we include the natural logarithm of gross total assets in real, 1994 dollars (LN(GTA)) and a dummy variable indicating whether the bank had GTA exceeding $\$ 10$ billion (GTA>10B). As shown, banks in the sample average about \$24 billion in GTA and about half had GTA over \$10 billion. We include three variables about the bank's financial condition: (1) the ratio of nonperforming loans to total loans (NPL); (2) the ratio of net income to equity (ROE); and (3) the ratio of equity to gross total assets (EQRAT). The local market variables measure market deposit concentration (M-HERF), nonperforming loans (M-NPL), profitability (M-ROE), and equity (M-EQRAT). The bank and local market data are constructed from the previous December's Call Reports to help mitigate potential endogeneity problems, and the market data are weighted averages across all the markets in which the bank has deposits, based on the previous June's Summary of Deposits data. ${ }^{14}$

We also control for a number of loan contract terms, including whether collateral is pledged (COLLATERAL), whether the loan is drawn under a commitment (COMMITMENT), the repayment duration of the loan (DURATION), whether the rate is floating (FLOATING RATE), and the total credit size, including the amount of any commitment (TOTAL SIZE). These contract terms help control for differences in credit risk, term premiums, and borrower heterogeneity. For the quantity regressions, we use the proportions of the bank's small business credits reported on the STBL over the year with the contract terms. As shown in Table 1, we designate these proportions with the prefix "P". For the price

\footnotetext{
14 Thus, the market variables are weighted-averages across all markets - either Metropolitan Statistical Areas (MSAs) or non-MSA counties - in which the bank has offices. The Summary of Deposits data contains the sole annual indication of individual bank branch locations. To illustrate, consider M-ROE for 1995 . We measure the 1995 M-ROE using year-end 1994 profitability information from all banks in each local market in which a sample bank operates. We then weight each market average with total deposit information on each local market as reported in June 1994 for each bank in our sample.
} 
and risk regressions, we include the terms associated with each individual loan. We recognize to some extent, the bank and firm may trade off between the price and the other contract terms, which introduces a potential endogeneity problem. As a consequence, we run all regressions both with and without contract terms to evaluate the robustness of our results.

Finally, the price and risk regressions include seasonal dummy variables that indicate the quarter in which the loan was made (Q1-Q4). The first quarter dummy Q1 is omitted from the price regressions as the base case, whereas both Q1 and Q2 are omitted from the risk regressions because the risk ratings were first collected in the second quarter of 1997.

\section{B. Regre ssion Specifications}

We specify the following three regressions for the quantity of small business credits under $100 \mathrm{~K}$ :

(1) SBL-RATIO $1=f$ (ADOPTED-SBCS 1, Bank and Market Variables, P-Loan Contract Terms),

(2) SBL-RATIO $1=g$ (ADOPTED-SBCS 1, TIME-SINCE 1, Bank and Market Variables, PLoan Contract Terms),

(3) SBL-RATIO $1=h$ (ADOPTED-SBCS 1, TIME-SINCE 1, BOUGHT 1, SET-TERMS 1 , AUTO-APPROVE 1, Bank and Market Variables, P-Loan Contract Terms),

where Bank and Market Variables, and P-Loan Contract Terms represent all the bank and market variables and average contract terms shown for the quantity regressions in Table 1.

Equations (1) - (3) are estimated both with and without the P-Loan Contract Terms by OLS. In Equation (1), we use ADOPTED-SBCS as a single indicator of SBCS to test for an overall impact of adoption. Comparing results across individual years allows us to test for an industrywide learning curve. Equation (2) adds the TIME-SINCE 1 variable to test for any bank-specific learning curves, or how the effects of SBCS change as time passes after its adoption. Equation (3) further allows SBCS to have different effects on lending quantities for "rules" banks versus "discretion" banks by including BOUGHT 1, SET-TERMS 1, and AUTO-APPROVE 1.

For credits between $100 \mathrm{~K}$ and $250 \mathrm{~K}$, we repeat the experiment substituting in the "2" data for these larger credits. However, we only estimate a version of Equation (1), and do not estimate versions of Equations (2) and (3) because of the limited variation in the survey responses for credits of this size. 
We specify the corresponding three regressions for the premiums on small business credits under 100K:

(4) PREM $1=f$ (ADOPTED-SBCS 1, Bank and Market Variables, Loan Contract Terms, Time Dummies),

(5) PREM $1=g$ (ADOPTED-SBCS 1, TIME-SINCE 1, Bank and Market Variables, Loan Contract Terms, Time Dummies),

(6) PREM $1=h$ (ADOPTED-SBCS 1, TIME-SINCE 1, BOUGHT 1, SET-TERMS 1, AUTOAPPROVE 1, Bank and Market Variables, Loan Contract Terms, Time Dummies),

where Bank and Market Variables, Loan Contract Terms, and Time Dummies represent all the bank and market variables, loan contract terms, and time dummies shown for the price regressions in Table 1.

Equations (4) - (6) are estimated both with and without the Loan Contract Terms by OLS. There are likely to be correlations across error terms for loans issued by the same bank during the same year due to unobserved variables. We cannot include fixed effects for each bank, which would be perfectly collinear with the ADOPTED-SBCS 1 variable. To address this issue, we compute the standard errors and test statistics using a White correction. Similar to the quantity regressions, we repeat the experiment for credits in the $100 \mathrm{~K}-250 \mathrm{~K}$ interval, but only estimate a version of Equation (4) because of limited variation in the data.

We specify the corresponding three regressions for the risk ratings of small business credits under 100K:

(7) RISK-RATING $1=f$ (ADOPTED-SBCS 1, Bank Variables, Loan Contract Terms, Time Dummies),

(8) RISK-RATING $1=g$ (ADOPTED-SBCS 1, TIME-SINCE 1, Bank Variables, Loan Contract Terms, Time Dummies),

(9) RISK-RATING $1=h$ (ADOPTED-SBCS 1, TIME-SINCE 1, BOUGHT 1, SET-TERMS 1 , AUTO-APPROVE 1, Bank Variables, Loan Contract Terms, Time Dummies),

Equations (7) - (9) are estimated both with and without the Loan Contract Terms by ordered logit. Notably, we exclude market variables because the presence of both bank and market variables in the specification creates large, conflicting coefficients among these variables. Importantly, the estimated 
coefficients of the key exogenous variables, the SBCS variables, are materially unaffected by the inclusion or exclusion of the market variables. We again repeat the experiment for credits in the $100 \mathrm{~K}$ $250 \mathrm{~K}$ interval, but only estimate a version of Equation (7) because of limited data variation.

All reported regressions exclude observations from banks that have adopted SBCS within the prior 12 months of the observed loan quantity, price, or risk rating used as the dependent variable. ${ }^{15}$ This reduces the possibility of three potential problems. First, although the SBCS survey indicates the month in which each bank adopted the technology, the timeframe for full SBCS implementation is uncertain and may vary across banks. By eliminating banks that recently began using SBCS, we can more confidently compare banks that had fully implemented SBCS technology to those banks that had not adopted SBCS. Second, the dependent variables in the quantity regressions may in some cases mix data on loans that were issued before and after SBCS was adopted, since SBL-RATIO 1,2 are stock measures that include both recently issued credits plus some longer-term credits issued in earlier periods. As shown in Table 1, the average repayment duration of the small business loans (P-DURATION 1,2) is less than one year, so we obtain a relatively clean comparison by restricting ourselves to comparing banks that have been using SBCS for a least one year with banks that have never adopted SBCS. Third, we reduce the possible endogeneity problem that the decision to adopt SBCS may be based on current conditions that also strongly affect loan quantities, prices, and risks. This potential endogeneity problem is mitigated by using quantity, price, and risk data that are at least one year after the adoption of SBCS, when conditions have changed to some degree.

\section{Empirical Results}

This section discusses the empirical effects of SBCS on the quantity, price, and risk of small business credits. First, we test the overall effects for small business credits under \$100,000 in 1997 (Table 2). Second, we test for the presence and slope of bank-specific learning curves (Table 3). Third, we test for the presence and slope of industrywide learning curves over the 1995-1997 interval (Table 4). Fourth, we test for differences between "rules" banks and "discretion" banks (Table 5). Fifth, we test the

\footnotetext{
${ }^{15}$ For the quantity regressions, we exclude banks that adopted SBCS less than 12 months before the June Call Report. For the price and risk regressions, we exclude banks that adopted SBCS less than 12 months before the date the loan was made.
} 
overall effect of SBCS for credits of 100K-250K in 1997 (Table 6). Finally, we report the results of two additional robustness checks (not shown in the tables).

\section{A. The Overall Effect of SBCS on Credits Under $\$ 100,000$}

Table 2 presents the overall effects of SBCS on the quantity, price, and risk of small business credits under $\$ 100,000$ for 1997 . Each regression is run twice: including and excluding the potentially endogenous loan contract terms. We estimate our empirical models using OLS for the quantity and price regressions (Panels 1 and 2) and ordered logit for the risk regressions (Panel 3).

The data suggest that SBCS is associated with higher small business loan ratios (Panel 1). The coefficient on ADOPTED-SBCS 1 (0.0051) implies about a 37\% higher small business loan ratio at the sample mean (0.0051/0.0138). This positive effect is consistent with prior research (Frame, Srinivasan, and Woosley, 2001, and Frame, Padhi, and Woosley, 2001). Although the result is statistically significant at only the ten percent level, the relationship is highly significant for some types of banks, as will be shown later. The positive relationship between SBCS and small business loan ratios is consistent with the empirical dominance of additional net lending to "marginal borrowers," possibly due to reduced lending costs or increased accuracy in evaluating creditworthiness.

We further find that SBCS is associated with higher loan prices (Panel 2). ${ }^{16}$ The coefficient on ADOPTED-SBCS 1 (0.0032) implies a 32 basis point difference in loan premiums, about 7\% higher at the sample mean $(0.0032 / 0.045)$. Given the quantity results, the positive relationship between SBCS and PREM suggests an empirical domination of higher average prices paid by the net additional "marginal borrowers" (due to the borrowers' higher risks, greater opacity, or higher lending costs), over lower average prices paid by "nonmarginal borrowers" (due to the bank's lower costs or improved accuracy from the implementation of SBCS).

We also find that SBCS is positively associated with loan risk (Panel 3). ${ }^{17}$ This is consistent with the quantity and price results, and suggests that the added "marginal borrowers" to which SBCS banks expand credit may represent, on average, greater risks than "nonmarginal borrowers" and/or any

\footnotetext{
${ }^{16}$ As an additional robustness check, we calculate the average premium for each bank and regress this measure on the SBCS variables, the bank and market control variables, and average loan contract terms. The positive relationship between SBCS adoption and loan premiums remains. However, the dramatic reduction in the number of observations (one per bank instead of one per loan) diminishes the statistical significance of the relationship.

${ }^{17}$ Our results are robust to the exclusion of 55 loans made by three banks that reported no variation in their risk ratings.
} 
"marginal borrowers" to which SBCS banks no longer extend credit. Additionally, the results could indicate that SBCS banks systematically evaluate "nonmarginal borrowers" as greater credit risks than other banks.

We assess the extent to which the higher average prices associated with SBCS (Panel 2) may be the result of greater average loan risk (Panel 3) as opposed to the result of higher average loan opacity or lending costs. As a rough test, we compare the results of two ancillary price regressions that employ only the data with valid risk ratings used in Panel $3(\mathrm{~N}=6564$, regressions not shown). The first of these price regressions uses the Panel 2 specification (with loan contract terms), while the second adds four risk rating dummy variables (based on RISK-RATING 1) as explanatory variables, excluding "minimal" risk as the base case. We recognize that loan price and risk may be simultaneously determined, so the risk ratings may be endogenous and the coefficients may be biased.

The results of this rough test suggest that higher loan risk does contribute to higher loan prices. When we include the risk rating dummies in the specification, their coefficients are positive and statistically significant, indicating that loans with greater than "minimal" risk are associated with higher PREM than loans rated "minimal" risk. Moreover, the adjusted R-squared improves from 0.1929 to 0.2326. However, loan risk does not fully explain the price differential between SBCS banks and nonSBCS banks. The coefficient on ADOPTED-SBCS 1 is only somewhat smaller when the risk rating dummies are included (0.0030 versus 0.0034$)$, and it remains statistically significant. Thus, other factors - such as greater informational opacity and/or higher lending costs for net additional "marginal borrowers" - also appear to help explain the price differential.

The coefficients on the individual control variables in the regressions reported in Table 2 are generally consistent with expectations. In Panel 1, increased bank size - measured by LN(GTA) and GTA $>10 B$ - is negatively related to the bank's portfolio share of small business loans, consistent with the extant literature. Results for bank health (NPL, ROE, EQRAT) and the health of banks in the market (MNPL, M-ROE, M-EQRAT) are mixed, while market concentration (M-HERF) is positively related to the bank's portfolio share of small business loans. The general lack of statistical significance among the control variables in the quantity regressions is not surprising given the limited number of degrees of freedom. 
In Panel 2, bank size is positively associated with higher loan prices. Results for bank health and market health are again mixed, while market concentration is associated with higher average prices, consistent with market power. The five loan contract terms are generally statistically significant. Loan commitments are positively related to prices, while collateral, duration, floating rates and loan size are negatively related to prices.

In Panel 3, bank size and bank health have mixed associations with loan risk. As noted, we exclude market control variables from the risk regressions but when both sets of variables are included, the findings for the key exogenous variable (ADOPTED-SBCS 1) are materially unchanged.

\section{B. Bank-Specific Learning Curves for Credits under $\$ \mathbf{1 0 0 , 0 0 0}$}

In Table 3, we test for the presence and slope of bank-specific SBCS learning curves for the quantity, price, and risk of small business credits under $\$ 100,000$ in 1997 by adding TIME-SINCE 1 to our empirical models. We also impute the cumulative effects of SBCS after $n$ years, $n=1,2,3$, by adding the ADOPTED-SBCS 1 coefficient and $n$ times the TIME-SINCE 1 coefficient. For example, as Panel 1 shows, the cumulative effect of SBCS on the small business lending ratio after three years is $0.0016+(3 * 0.00174)=0.0068$, which implies roughly a $49 \%$ higher small business credit ratio at the mean $(0.0068 / 0.0138)$.

In Panel 1, both ADOPTED-SBCS 1 and TIME-SINCE 1 are associated with higher small business loan ratios, although neither is statistically significant. Nonetheless, the imputed cumulative effects after both two and three years $(0.0051$ and 0.0068$)$ are statistically different from zero and consistent with the overall result shown above. The positive TIME-SINCE 1 coefficient suggests an upward sloping bank-specific learning curve for small business loan quantities, and implies a continued domination of increased lending to "marginal borrowers" over declines in lending to other "marginal borrowers" increases well after the initial SBCS adoption.

Turning to the bank-specific learning curve for loan premiums (Panel 2), both ADOPTED-SBCS 1 and TIME-SINCE 1 are positively associated with PREM 1. In the main specification, the TIMESINCE 1 coefficient is small and statistically insignificant, suggesting a relatively flat learning curve for loan premiums. By contrast, in the alternative specification that excludes contract terms, the TIMESINCE 1 coefficient is large and statistically significant, suggesting a relatively steep bank-specific 
learning curve for loan premiums. Despite this disparity, the cumulative effect in both cases after three years (34 and 44 basis points) is similar in magnitude to the overall impact discussed in Table 2.

A relatively flat bank-specific learning curve for loan prices would be consistent with an initial empirical dominance of higher prices paid by "marginal borrowers" over reductions in prices to "nonmarginal borrowers," followed in subsequent years by roughly offsetting price effects for these two groups. A relatively steep bank-specific learning curve for loan premiums would be consistent with a continuing domination of higher prices paid to additional "marginal borrowers" over any additional reductions in price to "nonmarginal borrowers."

Looking next at the slope of the bank-specific learning curve for loan risk (Panel 3), we find that more experience with SBCS is associated with greater loan risk. The positive and statistically significant TIME-SINCE 1 coefficient implies an upward sloping bank-specific learning curve for loan risk, and is consistent with the result that SBCS banks continue to increase lending to riskier "marginal borrowers" over time.

\section{Industrywide Learning Curves for Credits under $\$ \mathbf{1 0 0 , 0 0 0}$}

The banking industry as a whole may also learn collectively from its experience with SBCS over time. That is, an SBCS bank with $n$ years of experience with the technology may behave differently in later years. In Table 4, we test for the presence and slope of industrywide learning curves for the quantity and price of small business credits under 100K. Because the STBL began collecting risk ratings in 1997, we are unable extend the analysis to loan risk.

Table 4 shows the overall impact of SBCS on loan quantities (Panel 1) and prices (Panel 2) in 1995 and 1996. We cannot reasonably include TIME-SINCE 1 and impute cumulative effects for 1, 2, and 3 years because too few banks had significant experience with SBCS as of 1995. With regard to loan quantities, SBCS is not statistically related to differences in small business lending ratios in 1995 or 1996 (Table 4, Panel 1), but is associated with higher ratios in 1997 (Table 2, Panel 1). With regard to loan prices, the industrywide learning curve appears to be fairly steep: SBCS is associated with a -25 basis point difference in average loan premiums in 1995 (Table 4, Panel 2), an 8 basis point difference in 1996 (Table 4, Panel 2), and a 32 basis point difference in 1997 (Table 2, Panel 2).

These findings suggest that the banking industry may have experienced upward sloping 
industrywide learning curves of SBCS for both small business loan quantities and prices. Specifically, SBCS may have initially led to lower prices for "nonmarginal borrowers" due to cost savings or improved accuracy. Increased lending to "marginal borrowers" at higher prices may have followed. Due to the exclusion of TIME-SINCE 1 from the specification, we cannot rule out the hypothesis that bank-specific learning curves drive this industrywide learning curve.

\section{D. “Rules” Banks versus “Discretion” Banks for Credits under \$100,000}

To allow for differences in banks' SBCS implementation strategies, we delineate those banks that purchased their SBCS model (BOUGHT 1), used SBCS to set credit terms (SET-TERMS 1), and used SBCS to automate approval/rejection decisions (AUTO-APPROVE 1). We impute the cumulative effects of SBCS after $n$ years, $n=1,2,3$, for both "rules" banks and "discretion" banks. To be clear, we run the regressions for all banks and then impute separate effects for banks with "1s" for BOUGHT 1, SETTERMS 1 and AUTO-APPROVE 1 ("rules" banks) and banks with "Os" for those three variables

(“discretion" banks). As a rough correspondence, "rules" banks may be more likely to use SBCS as a substitute for other technologies in order to reduce costs, whereas "discretion" banks may be more likely to use SBCS as a complement to other technologies in order to improve accuracy. The results appear in Table 5.

The use of SBCS to set loan terms is associated with higher portfolio shares of small business credits (Panel 1). Although the other credit-scoring variables are statistically insignificant in this specification, the imputed cumulative effect of SBCS on small business loan ratios is positive and statistically significant for "rules" banks. Indeed, after three years of experience with SBCS, the imputed cumulative effect of 0.0147 suggests that a "rules" bank will increase its small business loan ratio by $106 \%$ at the sample mean $(0.0147 / 0.0138)$, consistent with the empirical dominance of some additional lending to "marginal borrowers" over any declines in lending to other "marginal borrowers." The imputed cumulative effect of SBCS for "discretion" banks is smaller and not statistically significant.

Next, we find that BOUGHT 1 and AUTO-APPROVE 1 are negatively associated with small business credit prices (Panel 2). The imputed cumulative effects of SBCS on PREM 1 for both "rules" banks and "discretion" banks are positive and statistically significant. However, the magnitude of the effect is much greater for "discretion" banks. After three years of experience with SBCS, the imputed 
cumulative effect of 0.0037 suggests that a "rules" bank will increase its average premium by 37 basis points, or $8 \%$ at the sample mean $(0.0037 / 0.045)$. In contrast, the imputed cumulative effect of 0.0199 for "discretion" banks implies an increase in average spreads by nearly 200 basis points, or 44\% $(0.0199 / 0.045){ }^{18}$ The result for "rules" banks is consistent with domination of higher average prices paid by the net additional "marginal borrowers" over lower average prices paid by "nonmarginal borrowers." The result for "discretion" banks is consistent with the domination of increased lending costs incurred due to the use of SBCS in conjunction with other lending technologies over any cost-savings that may be achieved by SBCS.

We further find that SET-TERMS 1 and AUTO-APPROVE 1 are positively associated loan risk (Panel 3). The imputed cumulative effects suggest that SBCS is associated with greater loan risk for "rules" banks but less loan risk for "discretion" banks. The result for "rules" banks suggests that the added "marginal borrowers" are relatively more risky than other borrowers. By contrast, for "discretion" banks, SBCS may improve accuracy, thereby lessening moral hazard/adverse selection and reducing average loan risk.

Thus, the data suggest that clear differences exist between "rules" banks and "discretion" banks. As previously argued, "rules" banks may be likely to use SBCS as a substitute for existing lending technology to reduce costs. For these banks, the results are consistent with a net increase in lending to "marginal borrowers," the dominance of higher average prices paid by these added "marginal borrowers" over reductions in prices paid by "nonmarginal borrowers," and a corresponding increase in average loan risk. By contrast, "discretion" banks are likely to use SBCS as a complement to existing lending technology to improve accuracy. The results for these banks are consistent with the domination of increased lending costs incurred due to the use of SBCS in conjunction with other lending technologies, but with corresponding reductions in average loan risk.

\section{E. Credits Between $\$ 100,000$ and $\$ 250,000$}

We also test the effects of SBCS on the quantity, price, and risk of small business loans of $100 \mathrm{~K}$ 250K. We limit our investigation to the overall effects of SBCS technology because of the limited

\footnotetext{
${ }^{18}$ As a robustness check, we allowed the bank-specific learning curves associated with loan prices to differ between "rules" banks and "discretion" banks. We found upward sloping learning curves for both types of SBCS banks.
} 
variation in survey responses for credits of this size. As examples, only eight banks reported using SBCS to set loan terms for loans of $100 \mathrm{~K}-250 \mathrm{~K}$, and only one bank used SBCS to automatic ally approve or reject these loans. The results, reported in Table 6, indicate that the adoption of SBCS has no statistically significant effect on the quantity of small business loans between $\$ 100,000$ and $\$ 250,000$ (Panel 1). However, SBCS is negatively related to loan prices (Panel 2). Indeed, the ADOPTED-SBCS 1 coefficient of -0.0014 implies that SBCS is associated with a difference in average loan premiums of -14 basis points, or $-3.5 \%$ at the sample mean (-0.0014/0.0398). Similarly, SBCS is significantly associated with lower loan risk (Panel 3). These findings are consistent with little net change in lending to "marginal borrowers" at these larger credit sizes, and reductions in average loan price and risk derived from improvements in accuracy and possibly lowered underwriting and monitoring costs.

\section{F. Additional Robustness Tests}

We conducted additional robustness tests to examine the problems associated with the inclusion of "new" credit scoring banks, and the possible portfolio substitution between consumer lending and small business lending. To conserve space, the results are not shown in the tables.

\section{Including observations from new credit scoring banks}

As discussed in Section V, we exclude observations from banks that adopted SBCS less than 12 months prior to the point of observation. The results are robust to the inclusion of these observations with one exception. Including new credit scoring banks, the overall effect of SBCS on the quantity of small business lending in 1997 is statistically insignificant. However, we do find that SBCS is associated with higher small business loan ratios when we allow for bank-specific learning curves and differences in implementation ("rules" versus "discretion"). All results examining the effect of SBCS on loan prices and risks are robust.

\section{Testing the "portfolio substitution" hypothesis}

The finding that SBCS is associated with increases in small business lending may alternatively be the result of portfolio substitution, or the process by which a bank would reclassify loans previously considered consumer loans. This could occur if firms obtained credit in the form of consumer loans to their owner prior to the introduction of SBCS. If the "portfolio substitution" hypothesis explains the increase in small business lending presented above, then we would likely find that SBCS is negatively 
associated with the quantity of consumer lending. To test the hypothesis, we regress the ratio of total consumer loans to gross total assets on the explanatory variables that appear in Tables 2 and 6 . Our results for both loans under $100 \mathrm{~K}$ and loans of $100 \mathrm{~K}-250 \mathrm{~K}$ show a positive, but statistically insignificant association between SBCS and the quantity of consumer lending. These results fail to support the "portfolio substitution" hypothesis.

\section{Conclusions}

This paper analyzes the economic effects of small business credit scoring (SBCS), a rapidly spreading and potentially important financial technology. We examine the relationships between SBCS and the quantity, price, and risk of small business credit, which may have a number of significant implications. Our empirical application combines data from a survey of banks' SBCS usage, a survey of individual bank loan prices, contract terms, and risk ratings, and several regulatory reports.

Our analytical framework provides some intuition about how the adoption of SBCS may change the way banks operate and alter small business credit availability, price, and risk. We show how SBCS may substitute for or serve as a complement to other lending technologies, and may in some cases result in the discontinued use of another technology. We distinguish between the effects of SBCS on "marginal borrowers" that gain access or lose access to credit as a result of the adoption of SBCS, and "nonmarginal borrowers" that would be approved for credit whether or not SBCS is adopted. We also distinguish between banks that rely more on "rules" - using automated price and approval/rejection decisions based on purchased credit scores - and banks that exercise more "discretion" - developing their own scoring models and using other inputs in credit decisions. "Rules" banks may be more likely to use SBCS as a substitute for other technologies in order to reduce lending costs, whereas "discretion" banks may be more likely to use SBCS as a complement to other technologies in order to improve accuracy in evaluating creditworthiness.

Our empirical models test a number of the implications of the framework. Specifically, we test for the effects of SBCS on the availability, price, and risk of small business credits of different sizes, test for the presence and slope of bank-specific and industrywide learning curves, and test for differences in the effects of SBCS for "rules" banks versus "discretion" banks. In contrast, the prior empirical literature 
on SBCS tested only for the effects of SBCS on the availability of small business credit to one credit size category.

The tests uncover a number of results that suggest that SBCS may have important effects on the market for small business credit. First, the data suggest that the adoption of SBCS is associated with overall expanded credit availability, higher prices, and greater loan risk for small business credits under $\$ 100,000$. Based on our analytical framework, we attribute this outcome to a net increase in lending to "marginal borrowers" that tend to pay relatively high loan prices because they generally have higher credit risk, greater informational opacity, and/or are more costly to serve than other borrowers that are not at the margin of acceptance/denial.

Second, both bank-specific and industrywide learning curves appear to be important. We find that, over time, SBCS is associated with expanding quantities of small business credit at rising average prices and increasing credit risk. This suggests that as individual banks and the banking industry as a whole gain experience with the new technology, banks using SBCS may increasingly expand lending to "marginal borrowers."

Third, the effects of SBCS appear to differ markedly depending on how a bank implements the technology. For "rules" banks, we find that SBCS is associated with more lending, higher prices, and greater loan risk. These findings are consistent with the hypothesis that when SBCS is used as a substitute for other lending technologies, reduced lending costs allow for a net increase in lending to "marginal borrowers." By contrast, for "discretion" banks, we find no statistically significant increase in credit availability, larger increases in loan prices relative to rules banks, and diminished loan risk. These results suggest that when SBCS is used as complement to another lending technology, lending costs may be increased, but the improved accuracy in credit evaluation may reduce risk.

Finally, for slightly larger credits $(\$ 100,000$ to $\$ 250,000)$, SBCS is associated with no significant change in credit availability, lower prices, and diminished loan credit risk. These results are consistent with price reductions to "nonmarginal borrowers" derived from improvements in accuracy in evaluating creditworthiness and possibly reductions in underwriting costs.

Our findings may have a number of important policy implications. For example, there has been an on-going concern that the consolidation of the banking industry may result in less credit available to 
small businesses. This concern is often based on the findings elsewhere that large banks - particularly those that have recently engaged in mergers and acquisitions - tend to devote relatively low proportions of their assets to small business loans. Our results suggest that this effect may be offset to some degree by SBCS, a technology that appears to allow some large banks to expand their lending to at least some pools of small business customers.

This research also raises a number of other policy-oriented questions that might usefully be addressed in future research, including:

(1) How will the nature of bank-borrower relationships evolve in response to the adoption of new technologies, such as SBCS? To what extent might traditional relationships based on "soft" nonquantitative information, such as the character and reliability of the firm's owner be replaced by impersonal use of "hard" quantitative data, such as owner's income, portfolio, and payment history?

(2) Will SBCS and other financial technology innovations change the way in which small businesses interact with financial institutions (personal contact versus Internet and other impersonal methods), and how will this affect the role of the loan officer?

(3) Are small businesses still locally constrained for funding, or is the market becoming more national or international? What are the implications of this change for antitrust policy regarding the banking industry, which is typically based on local market concentration?

(4) Have small banks lost an important comparative advantage to large banks due to SBCS? If so, what are the implications for the future of "community banking?" 


\section{REFERENCES}

Akhavein, J. Frame, W.S., and White, L.J., 2001. "The diffusion of financial innovation: An examination of the adoption of small business credit scoring by large banking organizations." Federal Reserve Bank of Atlanta Working Paper 2001-9.

Avery, R.B., Bostic, R.W., Calem, P.S., and Canner, G.B., 2000, Credit scoring: Statistical issues and evidence from credit bureau files, Real Estate Economics, 28, 523-547.

Berger, A.N., DeYoung, R., 2001, Technological progress and the geographic expansion of the banking industry, working paper, Federal Reserve Board.

Berger, A.N., Mester, L., 2001, Explaining the dramatic changes in performance of U.S. banks: Technological change, deregulation, and dynamic changes in competition," working paper, Federal Reserve Board.

Berger, A.N., Saunders, A., Scalise, J.M., Udell, G.F., 1998, The effects of bank mergers and acquisitions on small business lending, Journal of Financial Economics, 50, 187-229.

Berger, A.N., Udell, G.F., 2002, Small business credit availability and relationship lending: The importance of bank organizational structure, Economic Journal, 112, F32-F53.

Brady, T.F., English, W.B., and Nelson, W.R., 1998, Recent changes to the federal reserve's survey of terms of bank lending, Federal Reserve Bulletin, August, 604-615.

Cyrnak, A., Hannan, T., 2000, Non-local lending to small businesses," working paper, Federal Reserve Board.

Eisenbeis, R., 1996, Recent developments in the application of credit scoring techniques to the evaluation of commercial loans, IMA Journal of Mathematics Applied in Business and Industry, 7, 271-290.

Feldman, R., 1997, Small business loans, small banks and a big change in technology called credit scoring, Federal Reserve Bank of Minneapolis' The Region, September, 19-25.

Frame, W.S., Srinivasan, A., Woosley, L., 2001, The effect of credit scoring on small business lending, Journal of Money, Credit, and Banking, 33(3), 813-825.

Frame, W. S., Padhi, M., and Woolsey, L., 2001, "The effect of credit scoring on small business lending in low- and moderate income areas." Federal Reserve Bank of Atlanta Working Paper 2001-6.

Furst, K., Lang, W. and Nolle, D., 2000, "Internet banking: Developments and prospects," Office of the Comptroller of the Currency Working Paper 2000-9.

Gowrisankaran, G. and Stavins, J., 1999, "Network externalities and technology adoption: Lessons from electronic payments," Federal Reserve Bank of Boston Working Paper 1999-5.

Hand, D.J., Henley, W.E., 1997, Statistical classifications methods in consumer credit scoring: A review, Journal of the Royal Statistical Society, 160, 522-541. 
Hannan, T. and McDowell, J., 1984. "The determinants of technology adoption: The case of the banking firm," Rand Journal of Economics, 15, 328-335.

Kwast, M.L., Starr-McCluer, M., and Wolken, J.D., 1997, Market definition and the analysis of antitrust in banking, Antitrust Bulletin, 42(4), 973-995.

Mester, L., 1997, What's the point of credit scoring?, Federal Reserve Bank of Philadelphia Business Review, September/October, 3-16.

Petersen, M.A., Rajan, R.G., 2002, Does distance still matter? The information revolution in small business lending, Journal of Finance, forthcoming.

Rutherford, R., 1994/1995, Securitizing small business loans: A banker's action plan, Commercial Lending Review, 10(1), 62-74.

Saunders, A., 2000, Financial Institutions Management, Boston: Irwin McGraw-Hill.

Stiroh, K.J., 2000, How did bank holding companies prosper in the 1990s?, Journal of Banking and Finance, 24, 1703-1745.

Wheelock, D.C., and Wilson, P.W., 1999, Technical progress, inefficiency, and productivity change in U.S. banking, 1984-1993, Journal of Money, Credit, and Banking, 31, 212-234. 


\section{I'able I. Variable Definitions and Summary Statistics, 1995-1997}

Table 1 contains definitions and summary statistics for variables used in the estimation. The variables used in the quantity regressions represent bank observations and appear in columns 1 and 2. The data include 152 bank observations for credits under $\$ 100,000$ and 151 bank observations for credits between $\$ 100,000$ and $\$ 250,000$. The variables used in the price and risk regressions represent loan observations. The respective dependent variables, PREM 1,2 and RISK-RATING 1,2 appear in columns 3 and 4 together with the exogenous variables used in the price regressions. The means and standard deviations for the exogenous variables used in the risk regressions are not shown, and may differ somewhat from the sample statistics shown for the price regressions due to the smaller sample size. For the price regressions, the data include 33,561 loan observations for credits under $\$ 100,000$ and 13,058 loan observations for credits between $\$ 100,000$ and $\$ 250,000$. For the risk regressions, the data include 7,515 loan observations for credits under $\$ 100,000$ and 3,131 loan observations for credits between $\$ 100,000$ and $\$ 250,000$.

\begin{tabular}{|c|c|c|c|c|c|}
\hline \multirow[b]{2}{*}{ Variables } & \multirow[b]{2}{*}{ Definitions } & \multicolumn{2}{|c|}{$\begin{array}{l}\text { Means and Standard Deviations } \\
\text { by Bank (Quantity Regressions) }\end{array}$} & \multicolumn{2}{|c|}{\begin{tabular}{|c|} 
Means and Standard Deviations \\
by Loan (Price, Risk Regressions) \\
\end{tabular}} \\
\hline & & $\begin{array}{c}\text { Column 1: } \\
\text { Credits }<100 \mathrm{~K} \\
\end{array}$ & $\begin{array}{c}\text { Column 2: } \\
100 \mathrm{~K}<\text { Credits }<250 \mathrm{~K}\end{array}$ & $\begin{array}{l}\text { Column 3: } \\
\text { Credits }<100 \mathrm{~K} \\
\end{array}$ & $\begin{array}{c}\text { Column 4: } \\
100 \mathrm{~K}<\text { Credits }<250 \mathrm{~K}\end{array}$ \\
\hline \multicolumn{6}{|c|}{ 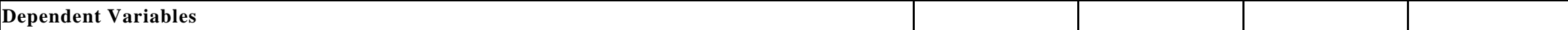 } \\
\hline SBL-RATIO 1,2 & Small business loans divided by gross total assets (GTA). & $\begin{array}{c}0.0138 \\
(0.0129)\end{array}$ & $\begin{array}{c}0.0088 \\
(0.0059)\end{array}$ & & \\
\hline PREM 1,2 & $\begin{array}{l}\text { Premium over the Treasury rate of comparable repayment duration. For } \\
\text { fixed-rate loans, we use a Treasury security with duration equal to that of } \\
\text { the loan. For floating-rate loans, we assume that the loans are expected } \\
\text { to be repriced within } 4 \text { weeks and use the Treasury rate with duration } \\
\text { equal to the minimum of the loans' durations and } 4 \text { weeks. }\end{array}$ & & & $\begin{array}{c}0.0450 \\
(0.0154)\end{array}$ & $\begin{array}{c}0.0398 \\
(0.0110)\end{array}$ \\
\hline RISK-RATING 1,2 & $\begin{array}{l}\text { The loan risk rating. RISK-RATING equals } 1 \text { if the loan has "minimal" } \\
\text { risk, } 2 \text { if the loan has "low" risk, } 3 \text { if the loan has "moderate" risk, } 4 \text { if the } \\
\text { loan has "acceptable" risk, and } 5 \text { if the loan is a special mention or } \\
\text { classified asset. }\end{array}$ & & & $\begin{array}{c}3.3136 \\
(0.7587)\end{array}$ & $\begin{array}{c}3.3772 \\
(0.7532)\end{array}$ \\
\hline \multicolumn{6}{|c|}{$\begin{array}{l}\text { Credit Scoring Variables } \\
(1 \text { applies to small business loans under 100K, } 2 \text { applies to small business loans between } 100 \mathrm{~K} \text { and } 250 \mathrm{~K} .)\end{array}$} \\
\hline ADOPTED SBCS 1,2 & Dummy indicating that the bank used credit scoring to evaluate loans. & $\begin{array}{c}0.4605 \\
(0.5001)\end{array}$ & $\begin{array}{c}0.3245 \\
(0.4697)\end{array}$ & $\begin{array}{c}0.6317 \\
(0.4823)\end{array}$ & $\begin{array}{c}0.4687 \\
(0.4990)\end{array}$ \\
\hline TIME SINCE 1,2 & Number of years since the bank began using a credit scoring model. & $\begin{array}{c}0.7100 \\
(1.1163)\end{array}$ & $\begin{array}{c}0.5099 \\
(0.9831)\end{array}$ & $\begin{array}{c}1.0204 \\
(1.1650)\end{array}$ & $\begin{array}{c}1.0798 \\
(1.2792)\end{array}$ \\
\hline BOUGHT 1,2 & Dummy indicating that the bank purchased its credit scoring model. & $\begin{array}{c}0.3816 \\
(0.4874)\end{array}$ & $\begin{array}{c}0.2914 \\
(0.4559)\end{array}$ & $\begin{array}{c}0.5857 \\
(0.4926)\end{array}$ & $\begin{array}{c}0.4603 \\
(0.4984)\end{array}$ \\
\hline SET TERMS 1,2 & Dummy indicating that the bank used credit scoring to set loan terms. & $\begin{array}{c}0.1579 \\
(0.3658)\end{array}$ & $\begin{array}{c}0.0728 \\
(0.2608)\end{array}$ & $\begin{array}{c}0.2283 \\
(0.4198)\end{array}$ & $\begin{array}{c}0.2354 \\
(0.4243)\end{array}$ \\
\hline AUTO APPROVE 1,2 & $\begin{array}{l}\text { Dummy indicating that the bank used credit scoring to automatically } \\
\text { approve or reject loans. }\end{array}$ & $\begin{array}{c}0.2434 \\
(0.4306)\end{array}$ & $\begin{array}{c}0.0199 \\
(0.1400)\end{array}$ & $\begin{array}{c}0.3509 \\
(0.4772)\end{array}$ & $\begin{array}{c}0.0129 \\
(0.1130)\end{array}$ \\
\hline \multicolumn{6}{|c|}{ Bank and Market Variables (as of December of the previous year) } \\
\hline GTA & $\begin{array}{l}\text { Gross total assets (GTA) (\$000, in real } 1994 \text { terms, (not included in } \\
\text { regressions)). }\end{array}$ & $\begin{array}{c}23,796,332 \\
(44,682,987)\end{array}$ & $\begin{array}{c}24,133,708 \\
(44,825,833)\end{array}$ & $\begin{array}{c}22,348,479 \\
(35,686,409)\end{array}$ & $\begin{array}{c}23,478,629 \\
(36,833,422)\end{array}$ \\
\hline LN(GTA) & Natural log of GTA. & $\begin{array}{c}16.14 \\
(1.1821)\end{array}$ & $\begin{array}{c}16.16 \\
(1.1849)\end{array}$ & $\begin{array}{c}16.31 \\
(1.0145)\end{array}$ & $\begin{array}{c}16.41 \\
(0.9764)\end{array}$ \\
\hline GTA $>10 B$ & Dummy indicating GTA $>\$ 10$ billion. & $\begin{array}{c}0.5066 \\
(0.5016)\end{array}$ & $\begin{array}{c}0.5099 \\
(0.5016)\end{array}$ & $\begin{array}{c}0.6563 \\
(0.4750)\end{array}$ & $\begin{array}{c}0.6107 \\
(0.4876)\end{array}$ \\
\hline
\end{tabular}




\begin{tabular}{|c|c|c|c|c|c|}
\hline \multirow{2}{*}{\multicolumn{2}{|c|}{ Definitions }} & \multicolumn{2}{|c|}{ by Bank (Quantity Regressions) } & \multicolumn{2}{|c|}{ by Loan (Price, Risk Regressions) } \\
\hline & & $\begin{array}{c}\text { Column 1: } \\
\text { Credits < 100K } \\
\end{array}$ & $\begin{array}{c}\text { Column 2: } \\
100 \mathrm{~K}<\text { Credits }<250 \mathrm{~K} \\
\end{array}$ & $\begin{array}{c}\text { Column 3: } \\
\text { Credits }<100 \mathrm{~K} \\
\end{array}$ & \begin{tabular}{c|c|} 
Column 4: \\
$100 \mathrm{~K}<$ Credits $<250 \mathrm{~K}$ \\
\end{tabular} \\
\hline \multicolumn{6}{|c|}{ Bank and Market Variables Continued (as of December of the previous year) } \\
\hline NPL & Bank's nonperforming loan ratio. & $\begin{array}{c}0.0133 \\
(0.0091)\end{array}$ & $\begin{array}{c}0.0134 \\
(0.0091)\end{array}$ & $\begin{array}{c}0.0129 \\
(0.0061)\end{array}$ & $\begin{array}{c}0.0129 \\
(0.0065)\end{array}$ \\
\hline ROE & Bank's return on equity. & $\begin{array}{c}0.1627 \\
(0.0516)\end{array}$ & $\begin{array}{c}0.1623 \\
(0.0513)\end{array}$ & $\begin{array}{c}0.1724 \\
(0.0454)\end{array}$ & $\begin{array}{c}0.1718 \\
(0.0493)\end{array}$ \\
\hline EQRAT & Bank's equity/GTA ratio. & $\begin{array}{c}0.0751 \\
(0.0146)\end{array}$ & $\begin{array}{c}0.0753 \\
(0.0145)\end{array}$ & $\begin{array}{c}0.0744 \\
(0.0132)\end{array}$ & $\begin{array}{c}0.0745 \\
(0.0135)\end{array}$ \\
\hline M-HERF & $\begin{array}{l}\text { Weighted average of Herfindahl indices of local markets in which the } \\
\text { bank has deposits. }\end{array}$ & $\begin{array}{c}0.1857 \\
(0.0705)\end{array}$ & $\begin{array}{c}0.1869 \\
(0.0697)\end{array}$ & $\begin{array}{c}0.1970 \\
(0.0543)\end{array}$ & $\begin{array}{c}0.1903 \\
(0.0548)\end{array}$ \\
\hline M-NPL & Weighted average of local market nonperforming loans. & $\begin{array}{c}0.0130 \\
(0.0041)\end{array}$ & $\begin{array}{c}0.0131 \\
(0.0040)\end{array}$ & $\begin{array}{c}0.0131 \\
(0.0036)\end{array}$ & $\begin{array}{c}0.0127 \\
(0.0034)\end{array}$ \\
\hline M-ROE & Weighted average of local market ROE. & $\begin{array}{c}0.1593 \\
(0.0312)\end{array}$ & $\begin{array}{c}0.1596 \\
(0.0304)\end{array}$ & $\begin{array}{c}0.1657 \\
(0.0260)\end{array}$ & $\begin{array}{c}0.1652 \\
(0.0271)\end{array}$ \\
\hline M-EQRAT & Weighted average of local market equity ratio. & $\begin{array}{c}0.0752 \\
(0.0105)\end{array}$ & $\begin{array}{c}0.0752 \\
(0.0105)\end{array}$ & $\begin{array}{c}0.0754 \\
(0.0101)\end{array}$ & $\begin{array}{c}0.0755 \\
(0.0109)\end{array}$ \\
\hline \multicolumn{6}{|c|}{$\begin{array}{l}\text { Loan Contract Terms } \\
\text { ( } 1 \text { applies to small business loans under } 100 \mathrm{~K}, 2 \text { applies to small business loans between } 100 \mathrm{~K} \text { and } 250 \mathrm{~K} \text {.) }\end{array}$} \\
\hline P-COLLATERAL 1,2 & Proportion of bank loans that are collateralized. & $\begin{array}{c}0.7367 \\
(0.2044)\end{array}$ & $\begin{array}{c}0.8085 \\
(0.1708)\end{array}$ & & \\
\hline P-COMMITMENT 1,2 & Proportion of bank loans drawn under a commitment. & $\begin{array}{c}0.5643 \\
(0.3415)\end{array}$ & $\begin{array}{c}0.7548 \\
(0.2862)\end{array}$ & & \\
\hline P-DURATION 1,2 & $\begin{array}{l}\text { The weighted-average scheduled time until the principal and interest } \\
\text { on the bank's average loan is repaid, discounted using the loan interest } \\
\text { rate. }\end{array}$ & $\begin{array}{c}0.8545 \\
(0.6186)\end{array}$ & $\begin{array}{c}0.8654 \\
(0.7828)\end{array}$ & & \\
\hline P-FLOATING RATE 1,2 & Proportion of bank loans with a floating rate of interest. & $\begin{array}{c}0.8417 \\
(0.2069)\end{array}$ & $\begin{array}{c}0.8809 \\
(0.2024)\end{array}$ & & \\
\hline P-TOTAL SIZE 1,2 & $\begin{array}{l}\text { Average size of bank loans, measured by the maximum of the loan } \\
\text { amount and the amount of commitment, if any. }\end{array}$ & $\begin{array}{c}44.80 \\
(13.76)\end{array}$ & $\begin{array}{l}172.62 \\
(17.36)\end{array}$ & & \\
\hline COLLATERAL 1,2 & Dummy indicating that the loan is collateralized. & & & $\begin{array}{c}0.7572 \\
(0.4288)\end{array}$ & $\begin{array}{c}0.8212 \\
(0.3832)\end{array}$ \\
\hline COMMITMENT 1,2 & Dummy indicating that the bank has issued a commitment on the loan. & & & $\begin{array}{c}0.5155 \\
(0.4998)\end{array}$ & $\begin{array}{c}0.7843 \\
(0.4113)\end{array}$ \\
\hline DURATION 1,2 & $\begin{array}{l}\text { The scheduled time until the principal and interest on the loan is } \\
\text { repaid, discounted using the loan interest rate. }\end{array}$ & & & $\begin{array}{c}0.7482 \\
(0.9666)\end{array}$ & $\begin{array}{c}0.7710 \\
(1.0575)\end{array}$ \\
\hline FLOATING RATE 1,2 & Dummy indicating a floating rate of interest on the loan. & & & $\begin{array}{c}0.8933 \\
(0.3088)\end{array}$ & $\begin{array}{c}0.9352 \\
(0.2462)\end{array}$ \\
\hline TOTAL SIZE 1,2 & $\begin{array}{l}\text { The size of the loan, measured by the maximum of the loan amount } \\
\text { and the amount of commitment, if any. }\end{array}$ & & & $\begin{array}{c}39.86 \\
(29.31)\end{array}$ & $\begin{array}{l}176.05 \\
(43.95)\end{array}$ \\
\hline \multicolumn{6}{|l|}{ Time Dummies } \\
\hline Q1-Q4 & $\begin{array}{l}\text { Dummies indicating the quarter in which the loan was made (price and } \\
\text { risk regressions only). In the price regressions, Q1 is excluded as the } \\
\text { base case. In the risk regressions, Q1 and Q2 are excluded as base } \\
\text { cases. }\end{array}$ & & & & \\
\hline
\end{tabular}


Table 2. Overall Effects of SBCS on small business loan ratios, loan premiums, and loan risk ratings, 1997.

Regressions for SBL-RATIO 1, the ratio of small business loans under $\$ 100,000$ to gross total assets, PREM, the premium over the Treasury rate of comparable repayment duration for loans under $\$ 100,000$, and RISK-RATING 1, which equals 1 if the loan has "minimal" risk, 2 if the loan has "low" risk, 3 if the loan has "moderate" risk, 4 if the loan has "acceptable" risk, and 5 if the loan is a special mention or classified asset. Data are taken for 1997 . Number of observations varies across regressions. Where SBL-RATIO 1 is the dependent variable, the contract terms are bank averages. Where PREM 1 is the dependent variable, the regression also includes Q2, Q3 and Q4, which indicate the quarter in which the loan was made, and t-statistics are adjusted for heteroskedasticity and cross-correlations using the White correction. Where RISK-RATING 1 is the dependent variable, the regression also includes Q3 and Q4, which indicate the quarter in which the loan was made. Significance at the $10 \%, 5 \%$ and $1 \%$ levels denoted by *,**, and *** respectively.

\begin{tabular}{|c|c|c|c|c|c|c|c|c|c|c|c|c|}
\hline \multirow{3}{*}{\begin{tabular}{|l} 
Dependent Variable: \\
$\underline{\text { Variable }}$
\end{tabular}} & \multirow{2}{*}{\multicolumn{4}{|c|}{$\begin{array}{c}\text { SBL-RATIO } 1 \text { (Panel 1, OLS) } \\
\begin{array}{c}\text { Nontract Terms } \\
\text { No Contract Terms }\end{array}\end{array}$}} & \multicolumn{4}{|c|}{ PREM 1 (Panel 2, OLS) } & \multicolumn{4}{|c|}{ RISK-RATING 1 (Panel 3, Ordered Logit) } \\
\hline & & & & & \multicolumn{2}{|c|}{ Contract Terms } & \multicolumn{2}{|c|}{ No Contract Terms } & \multicolumn{2}{|c|}{ Contract Terms } & \multicolumn{2}{|c|}{ No Contract Terms } \\
\hline & $\underline{\text { Coefficient }}$ & $\underline{\text { T-Stat }}$ & $\underline{\text { Coefficient }}$ & $\underline{\mathrm{T} \text {-Stat }}$ & $\underline{\text { Coefficient }}$ & $\underline{\text { T-Stat }}$ & $\underline{\text { Coefficient }}$ & $\underline{T-S t a t}$ & $\underline{\text { Coefficient }}$ & $\underline{\mathrm{T} \text {-Stat }}$ & $\underline{\text { Coefficient }}$ & $\underline{\text { T-Stat }}$ \\
\hline INTERCEPT1 & 0.0300 & 0.88 & 0.0249 & 0.85 & $-0.0175 * * *$ & -3.71 & $-0.0396 * * *$ & -7.88 & $1.8767 * * *$ & 2.86 & $0.9665 *$ & 1.67 \\
\hline INTERCEPT2 & & & & & & & & & $4.5621 * * *$ & 6.93 & $3.6354 * * *$ & 6.28 \\
\hline INTERCEPT3 & & & & & & & & & $7.6467 * * *$ & 11.55 & $6.7022 * * *$ & 11.52 \\
\hline \multirow[t]{2}{*}{ INTERCEPT4 } & & & & & & & & & $9.2146 * * *$ & 13.83 & $8.2719 * * *$ & 14.10 \\
\hline & & & & & \multicolumn{4}{|c|}{ Credit Scoring Variables } & & & & \\
\hline ADOPTED-SBCS 1 & $0.0051 *$ & 1.77 & $0.0052 *$ & 2.02 & $0.0032 * * *$ & 9.22 & $0.0035 * * *$ & 9.41 & $0.5383 * * *$ & 7.61 & $0.4917 * * *$ & 7.16 \\
\hline & & & & & \multicolumn{4}{|c|}{ Bank and Market Variables } & & & & \\
\hline LN(GTA) & $-0.0033 *$ & -1.99 & $-0.0031 * *$ & -2.09 & $0.0021 * * *$ & 8.56 & $0.0030 * * *$ & 11.09 & $-0.2309 * * *$ & -6.21 & $-0.2314 * * *$ & -6.47 \\
\hline GTA $>10 B$ & -0.0008 & -0.21 & -0.0012 & -0.34 & $0.0012 * * *$ & 2.65 & $0.0011 * *$ & 2.368 & $0.8548 * * *$ & 10.90 & $0.8874 * * *$ & 11.78 \\
\hline NPL & -0.0457 & -0.24 & -0.0437 & -0.27 & $0.1945 * * *$ & 7.42 & $0.3605 * * *$ & 12.38 & -1.5631 & -0.49 & -1.0742 & -0.34 \\
\hline ROE & -0.0501 & -1.37 & -0.0557 & -1.68 & $0.0462 * * *$ & 9.84 & $0.0777 * * *$ & 15.4 & $3.6859 * * *$ & 5.34 & $4.1528 * * *$ & 6.16 \\
\hline EQRAT & $0.1986^{*}$ & 2.03 & $0.1912 * *$ & 2.23 & -0.0070 & -0.53 & $0.0412 * * *$ & 2.839 & $-23.9608 * * *$ & -10.74 & $-24.4798 * * *$ & -11.14 \\
\hline M-HERF & 0.0247 & 1.48 & 0.0211 & 1.44 & $0.0077 * * *$ & 3.43 & $0.0254 * * *$ & 10.93 & & & & \\
\hline M-NPL & -0.3981 & -0.72 & -0.4288 & -0.91 & -0.0172 & -0.30 & $-0.1374 * *$ & -2.264 & & & & \\
\hline M-ROE & 0.0857 & 1.37 & 0.0757 & 1.35 & $-0.0347 * * *$ & -3.15 & $-0.0737 * * *$ & -6.194 & & & & \\
\hline \multirow[t]{2}{*}{ M-EQRAT } & $0.2702 * *$ & 2.21 & $0.2824 * *$ & 2.52 & $0.2277 * * *$ & 16.16 & $0.1648 * * *$ & 11.01 & & & & \\
\hline & & & & & \multicolumn{4}{|c|}{ Loan Contract Terms } & & & & \\
\hline (P)COLLATERAL 1 & -0.0024 & -0.34 & & & $-0.0013 * * *$ & -3.92 & & & $0.2305 * * *$ & 3.97 & & \\
\hline (P)COMMITMENT 1 & -0.0028 & -0.73 & & & $0.0072 * * *$ & 26.25 & & & $-0.1101 * *$ & -2.02 & & \\
\hline (P)DURATION 1 & 0.0015 & 0.47 & & & $-0.0031 * * *$ & -22.73 & & & -0.0168 & 0.69 & & \\
\hline (P)FLOATING RATE 1 & -0.0055 & -0.59 & & & $-0.0017 * * *$ & -3.09 & & & $-1.0876 * * *$ & -5.49 & & \\
\hline (P)TOTAL SIZE 1 & 0.0000 & 0.36 & & & $-0.0001 * * *$ & -28.00 & & & $0.0022 * *$ & 2.49 & & \\
\hline Adj. R-Squared & 0.5078 & & 0.5664 & & 0.2573 & & 0.1459 & & & & & \\
\hline $\mathrm{N}$ & 41 & & 41 & & 13,589 & & 13,589 & & 6,564 & & 6,564 & \\
\hline
\end{tabular}


Table 3. Bank-specific learning curves for small business loan ratios, loan premiums, and loan risk ratings, 1997

Regressions for SBL-RATIO 1, the ratio of sm all business loans under $\$ 100,000$ to gross total assets, PREM, the premium over the Treasury rate of comparable repayment duration for loans under \$100,000, and RISK-RATING 1, which equals 1 if the loan has "minimal" risk, 2 if the loan has "low" risk, 3 if the loan has "moderate" risk, 4 if the loan has "acceptable" risk, and 5 if the loan is a special mention or classified asset. Data are taken for 1997. Number of observations varies across regressions. Numbers in italics represent imputed cumulative effects and their $\mathrm{t}$-statistics. Where SBL-RATIO 1 is the dependent variable, the contract terms are bank averages. Where PREM 1 is the dependent variable, the regression also includes $\mathrm{Q} 2, \mathrm{Q} 3$ and $\mathrm{Q} 4$, which indicate the quarter in which the loan was made, and t-statistics are adjusted for heteroskedasticity and cross-correlations using the White correction Where RISK-RATING 1 is the dependent variable, the regression also includes Q3 and Q4, which indicate the quarter in which the loan was made. Significance at the 10\%,5\% and 1\% Where RISK-RATING 1 is the dependent variable,
levels denoted by *,**, and *** respectively.

\begin{tabular}{|c|c|c|c|c|c|c|c|c|c|c|c|c|}
\hline \multirow{3}{*}{\begin{tabular}{|l} 
Dependent Variable: \\
$\underline{\text { Variable }}$
\end{tabular}} & \multicolumn{4}{|c|}{ SBL-RATIO 1 (Panel 1, OLS) } & \multicolumn{4}{|c|}{ PREM 1 (Panel 2, OLS) } & \multicolumn{4}{|c|}{ RISK-RATING 1 (Panel 3, Ordered Logit) } \\
\hline & \multicolumn{2}{|c|}{ Contract Terms } & \multicolumn{2}{|c|}{ No Contract Terms } & \multicolumn{2}{|c|}{ Contract Terms } & \multicolumn{2}{|c|}{ No Contract Terms } & \multicolumn{2}{|c|}{ Contract Terms } & \multicolumn{2}{|c|}{ No Contract Terms } \\
\hline & $\underline{\text { Coefficient }}$ & $\underline{\text { T-Stat }}$ & $\underline{\text { Coefficient }}$ & $\underline{\text { T-Stat }}$ & $\underline{\text { Coefficient }}$ & $\underline{\mathrm{T} \text {-Stat }}$ & $\underline{\text { Coefficient }}$ & $\underline{\mathrm{T} \text {-Stat }}$ & $\underline{\text { Coefficient }}$ & $\underline{\mathrm{T}-\text { Stat }}$ & $\underline{\text { Coefficient }}$ & $\underline{\text { T-Stat }}$ \\
\hline INTERCEPT1 & 0.0449 & 1.21 & 0.0305 & 1.00 & $-0.0173 * * *$ & -3.64 & $-0.0368 * * *$ & -7.16 & $2.4924 * * *$ & 3.76 & $1.7745 * * *$ & 3.01 \\
\hline INTERCEPT2 & & & & & & & & & $5.1971 * * *$ & 7.80 & $4.4611 * * *$ & 7.55 \\
\hline INTERCEPT3 & & & & & & & & & $8.2885 * * *$ & 12.38 & $7.5379 * * *$ & 12.69 \\
\hline \multirow[t]{2}{*}{ INTERCEPT4 } & & & & & & & & & $9.8605 * * *$ & 14.63 & $9.1116 * * *$ & 15.22 \\
\hline & & & & & \multicolumn{4}{|c|}{ Credit Scoring Variables } & & & & \\
\hline ADOPTED-SBCS 1 & 0.0016 & 0.36 & 0.0028 & 0.68 & $0.0026 * * *$ & 5.38 & 0.0007 & 1.39 & -0.0080 & -0.08 & -0.0485 & -0.48 \\
\hline \multirow[t]{2}{*}{ TIME-SINCE 1} & 0.0017 & 0.97 & 0.0011 & 0.75 & 0.0003 & 1.55 & $0.0012 * * *$ & 7.35 & $0.2451 * * *$ & 7.21 & $0.2452 * * *$ & 7.35 \\
\hline & \multicolumn{8}{|c|}{ Imputed Cumulative Effects of SBCS } & & & & \\
\hline After 1 year & 0.0034 & 0.99 & 0.0039 & 1.25 & $0.0029 * * *$ & 7.35 & $0.0019 * * *$ & 4.62 & $0.2371 * * *$ & 2.90 & $0.1967 * * *$ & 2.48 \\
\hline After 2 years & $0.0051 *$ & 1.77 & $0.0050 *$ & 1.93 & $0.0031 * * *$ & 8.97 & $0.0032 * * *$ & 8.68 & $0.4822 * * *$ & 6.77 & $0.4419 * * *$ & 6.41 \\
\hline \multirow[t]{2}{*}{ After 3 years } & $0.0068 * *$ & 2.01 & $0.0061 * *$ & 2.13 & $0.0034 * * *$ & 9.08 & $0.0044 * * *$ & 11.01 & $0.7273 * * *$ & 9.59 & $0.6871 * * *$ & 9.32 \\
\hline & \multicolumn{8}{|c|}{ Bank and Market Variables } & & & & \\
\hline LN(GTA) & $-0.0039 * *$ & -2.21 & $-0.0034 * *$ & -2.20 & $0.0021 * * *$ & 8.36 & $0.0028 * * *$ & 10.18 & $-0.2606 * * *$ & -6.93 & $-0.2663 * * *$ & -7.35 \\
\hline GTA $>10 B$ & 0.0002 & 0.04 & -0.0006 & -0.18 & $0.0012 * * *$ & 2.61 & $0.0010 * *$ & 2.24 & $0.8736 * * *$ & 11.10 & $0.8950 * * *$ & 11.85 \\
\hline NPL & 0.0032 & 0.02 & -0.0110 & -0.06 & $0.1967 * * *$ & 7.53 & $0.3594 * * *$ & 12.91 & -0.1464 & -0.05 & -0.2216 & -0.07 \\
\hline ROE & -0.0443 & -1.20 & -0.0513 & -1.51 & $0.0457 * * *$ & 9.80 & $0.0735 * * *$ & 14.62 & $4.4276 * * *$ & 6.33 & $4.8836 * * *$ & 7.15 \\
\hline EQRAT & 0.1636 & 1.57 & $0.1633 *$ & 1.74 & -0.0126 & -0.96 & 0.0084 & 0.59 & $-28.2805 * * *$ & -12.24 & $-29.1438 * * *$ & -12.78 \\
\hline M-HERF & 0.0246 & 1.48 & 0.0220 & 1.48 & $0.0077 * * *$ & 3.40 & $0.0242 * * *$ & 10.38 & & & & \\
\hline M-NPL & -0.4698 & -0.84 & -0.4603 & -0.96 & -0.0319 & -0.54 & $-0.2044 * * *$ & -3.36 & & & & \\
\hline M-ROE & 0.0898 & 1.43 & 0.0757 & 1.34 & $-0.0310 * * *$ & -2.77 & $-0.0542 * * *$ & -4.47 & & & & \\
\hline \multirow[t]{2}{*}{ M-EQRAT } & $0.2812 * *$ & 2.29 & $0.2880 * *$ & 2.55 & $0.2305 * * *$ & 16.49 & $0.1814 * * *$ & 12.29 & & & & \\
\hline & \multicolumn{8}{|c|}{ Loan Contract Terms } & & & & \\
\hline (P)COLLATERAL 1 & -0.0036 & -0.51 & & & $-0.0013 * * *$ & -4.11 & & & $0.2421 * * *$ & 4.16 & & \\
\hline (P)COMMITMENT 1 & -0.0028 & -0.73 & & & $0.0072 * * *$ & 25.45 & & & $-0.1458 * * *$ & -2.66 & & \\
\hline (P)DURATION 1 & 0.0004 & 0.13 & & & $-0.0031 * * *$ & -22.48 & & & 0.0046 & 0.19 & & \\
\hline (P)FLOATING RATE1 & -0.0066 & -0.70 & & & $-0.0016 * * *$ & -2.85 & & & $-1.0093 * * *$ & -5.07 & & \\
\hline (P)TOTAL SIZE 1 & 0.0000 & 0.08 & & & $-0.0001 * * *$ & -27.86 & & & $0.0018 * *$ & 1.98 & & \\
\hline Adj. R-Squared & 0.5068 & & 0.5601 & & 0.2574 & & 0.1495 & & & & & \\
\hline $\mathrm{N}$ & 41 & & 41 & & 13,589 & & 13,589 & & 6,564 & & 6,564 & \\
\hline
\end{tabular}


Table 4. Industrywide learning curves for small business loan ratios and loan premiums, 1995 and 1996

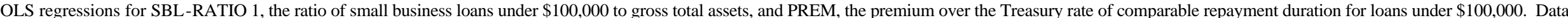

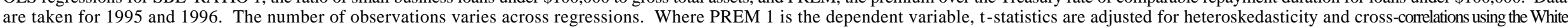
correction and regressions include Q2, Q3 and Q4, which indicate the quarter in which the loan was made. Significance at the $10 \%, 5 \%$ and $1 \%$ levels denoted by *,**, and *** respectively.

\begin{tabular}{|c|c|c|c|c|c|c|c|c|c|c|c|c|c|c|c|c|}
\hline \multirow{4}{*}{\begin{tabular}{|l} 
Dependent Variable: \\
Variable \\
\end{tabular}} & \multicolumn{8}{|c|}{ SBL-RATIO 1 (Panel 1, OLS) } & \multicolumn{8}{|c|}{ PREM 1 (Panel 2, OLS) } \\
\hline & \multirow{3}{*}{\multicolumn{2}{|c|}{\begin{tabular}{|r}
19 \\
Contract Terms \\
$\underline{\text { Coefficient }} \underline{\text { T-Stat }}$ \\
\end{tabular}}} & \multicolumn{2}{|c|}{95} & \multirow{2}{*}{\multicolumn{4}{|c|}{\begin{tabular}{|c|}
1996 \\
Contract Terms No Contract Terms \\
\end{tabular}}} & \multirow{2}{*}{\multicolumn{4}{|c|}{\begin{tabular}{|cc|}
\multicolumn{2}{|c|}{1995} \\
Contract Terms $\quad$ No Contract Terms \\
\end{tabular}}} & \multicolumn{4}{|c|}{1996} \\
\hline & & & \multicolumn{2}{|c|}{ No Contract Terms } & & & & & & & & & \multirow{3}{*}{$\frac{\text { Contract T }}{\underline{\text { Coefficient }}}$} & erms & No Contract & Terms \\
\hline & & & $\underline{\text { Coefficient }}$ & $\underline{T-S t a t}$ & \multicolumn{2}{|c|}{ Coefficien 1 T-Stat } & \multicolumn{2}{|c|}{ Coefficient T-Stat } & \multirow{2}{*}{$\frac{\text { Coefficient }}{-0.0827 * * *}$} & \multirow{2}{*}{$\frac{\mathrm{T}-\mathrm{Stat}}{-14.12}$} & \multirow{2}{*}{$\frac{\text { Coefficient }}{-0.1022 * * *}$} & \multirow{2}{*}{$\frac{\mathrm{T}-\text { Stat }}{-14.83}$} & & \multirow{2}{*}{$\frac{\text { T-Stat }}{14.29}$} & \multirow{2}{*}{$\frac{\text { Coefficient }}{0.0991 * * *}$} & \multirow{2}{*}{$\frac{\text { T-Stat }}{17.68}$} \\
\hline INTERCEPT & 0.0800 & 1.42 & 0.0325 & 0.71 & -0.1073 & -0.66 & -0.0147 & -0.14 & & & & & & & & \\
\hline & \multicolumn{16}{|c|}{ Credit Scoring Variables } \\
\hline \multirow[t]{2}{*}{ ADOPTED-SBCS 1} & -0.0029 & -0.50 & -0.0007 & -0.16 & 0.0010 & 0.07 & 0.0038 & 0.41 & $-0.0025 * * *$ & -5.07 & $-0.0030 * * *$ & -5.83 & $0.0008 *$ & 1.93 & 0.0002 & 0.42 \\
\hline & \multicolumn{16}{|c|}{ Bank and Market Variables } \\
\hline LN(GTA) & -0.0036 & -1.20 & -0.0011 & -0.47 & 0.0058 & 0.65 & 0.0008 & 0.14 & $0.0068 * * *$ & 21.55 & $0.0080 * * *$ & 21.08 & $-0.0023 * * *$ & -8.00 & $-0.0032 * * *$ & -10.78 \\
\hline GTA $>10 B$ & -0.0032 & -0.52 & -0.0067 & -1.23 & -0.0206 & -1.28 & -0.0143 & -1.12 & $-0.0070 * * *$ & -12.80 & $-0.0075 * * *$ & -12.25 & $0.0065 * * *$ & 9.97 & $0.0079 * * *$ & 12.29 \\
\hline NPL & -0.0477 & -0.16 & 0.1102 & 0.45 & -0.3130 & -0.27 & -0.2453 & -0.27 & $0.3797 * * *$ & 12.86 & $0.5580 * * *$ & 18.91 & $0.8133 * * *$ & 13.79 & $0.9727 * * *$ & 16.60 \\
\hline ROE & 0.0574 & 1.20 & 0.0375 & 0.85 & -0.0165 & -0.19 & 0.0068 & 0.09 & $0.0174 * * *$ & 3.01 & $0.0223 * * *$ & 3.51 & 0.0071 & 1.64 & $0.0099 * *$ & 2.28 \\
\hline EQRAT & 0.0056 & 0.03 & 0.0167 & 0.10 & -0.0051 & -0.01 & -0.0283 & -0.08 & $-0.1677 * * *$ & -10.30 & $-0.2432 * * *$ & -14.72 & $-0.3337 * * *$ & -20.51 & $-0.3904 * * *$ & -24.76 \\
\hline M-HERF & $0.0534 *$ & 1.75 & 0.0454 & 1.76 & 0.0458 & 0.59 & 0.0305 & 0.51 & $-0.0059 * *$ & -2.02 & 0.0009 & 0.29 & $-0.0066 * *$ & -2.24 & -0.0015 & -0.48 \\
\hline M-NPL & -0.3679 & -0.81 & -0.4721 & -1.17 & 0.3550 & 0.16 & -0.2117 & -0.12 & $0.1560 * * *$ & 3.38 & $0.1359 * * *$ & 2.81 & $-0.8246 * * *$ & -11.46 & $-0.8444 * * *$ & -12.57 \\
\hline M-ROE & -0.1201 & -1.34 & -0.0870 & -1.10 & 0.0116 & 0.06 & 0.0190 & 0.12 & 0.0127 & 1.40 & 0.0010 & 0.10 & $-0.0293 * * *$ & -3.89 & $-0.0576 * * *$ & -7.36 \\
\hline \multirow[t]{2}{*}{ M-EQRAT } & 0.0588 & 0.26 & 0.0556 & 0.26 & 0.3878 & 0.78 & 0.2805 & 0.68 & $0.3840 * * *$ & 21.53 & $0.4305 * * *$ & 23.99 & $0.3223 * * *$ & 18.68 & $0.3244 * * *$ & 17.92 \\
\hline & \multicolumn{16}{|c|}{ Loan Contract Terms } \\
\hline (P)COLLATERAL 1 & -0.0159 & -1.58 & & & -0.0062 & -0.19 & & & $-0.0024 * * *$ & -6.96 & & & $0.0012 * * *$ & 3.43 & & \\
\hline (P)COMMITMENT 1 & 0.0017 & 0.29 & & & 0.0073 & 0.31 & & & $0.0070 * * *$ & 20.48 & & & $0.0044 * * *$ & 12.99 & & \\
\hline (P)DURATION 1 & -0.0014 & -0.39 & & & 0.0061 & 0.73 & & & $-0.0026 * * *$ & -14.95 & & & $-0.0026 * * *$ & -15.65 & & \\
\hline (P)FLOATING RATE 1 & -0.0025 & -0.23 & & & 0.0266 & 1.21 & & & $0.0060 * * *$ & 10.51 & & & -0.0004 & -0.73 & & \\
\hline (P)TOTAL SIZE 1 & 0.0001 & 0.78 & & & -0.0005 & -0.80 & & & $-0.0001 * * *$ & -26.74 & & & $-0.0001 * * *$ & -16.16 & & \\
\hline Adj. R-Squared & 0.1363 & & 0.1692 & & -0.3294 & & -0.1539 & & 0.3976 & & 0.2573 & & 0.2385 & & 0.1728 & \\
\hline $\mathrm{N}$ & 46 & & 46 & & 33 & & 33 & & 7328 & & 7328 & & 7194 & & 7194 & \\
\hline
\end{tabular}


Table 5. "Rules" banks versus "Discretion" banks for small business loan ratios, loan premiums, and loan risk ratings, 1997

Regressions for SBL-RATIO 1, the ratio of small business loans under $\$ 100,000$ to gross total assets, PREM, the premium over the Treasury rate of comparable repayment duration for loans under $\$ 100,000$, and RISK-RATING 1, which equals 1 if the loan has "minimal" risk, 2 if the loan has "low" risk, 3 if the loan has "moderate" risk, 4 if the loan has "acceptable" risk, and 5 if the loan is a special mention or classified asset. Data are taken for 1997. Number of observations varies across regressions. Numbers in italics represent imputed cumulative effects and their t-statistics. Where SBL-RATIO 1 is the dependent variable, the contract terms are bank averages. Where PREM 1 is the dependent variable, the regression also includes Q2, Q3 and Q4, which indicate the quarter in which the loan was made, and $\mathrm{t}$-statistics are adjusted for heteroskedasticity and cross-correlations using the White correction. Where RISK-RATING 1 is the dependent variable, the regression also includes Q3 and Q4, which indicate the quarter in which the loan was made. Significance at the $10 \%, 5 \%$ and $1 \%$ levels denoted by *, **, and $* * *$ respectively.

\begin{tabular}{|c|c|c|c|c|c|c|c|c|c|c|c|c|}
\hline \multirow{3}{*}{\begin{tabular}{|l|} 
Dependent Variable: \\
$\underline{\text { Variable }}$
\end{tabular}} & \multicolumn{4}{|c|}{ SBL-RATIO 1 (Panel 1, OLS) } & \multicolumn{4}{|c|}{ PREM 1 (Panel 2, OLS) } & \multicolumn{4}{|c|}{ RISK-RATING 1 (Panel 3, Ordered Logit) } \\
\hline & \multicolumn{2}{|c|}{ Contract Terms } & \multicolumn{2}{|c|}{ No Contract Terms } & \multicolumn{2}{|c|}{ Contract Terms } & \multicolumn{2}{|c|}{ No Contract Terms } & \multicolumn{2}{|c|}{ Contract Terms } & \multicolumn{2}{|c|}{ No Contract Terms } \\
\hline & $\underline{\text { Coefficient }}$ & $\underline{\mathrm{T} \text {-Stat }}$ & $\underline{\text { Coefficient }}$ & $\underline{\mathrm{T} \text {-Stat }}$ & $\underline{\text { Coefficient }}$ & $\underline{\mathrm{T} \text {-Stat }}$ & $\underline{\text { Coefficient }}$ & $\underline{T-S t a t}$ & $\underline{\text { Coefficient }}$ & $\underline{\mathrm{T} \text {-Stat }}$ & $\underline{\text { Coefficient }}$ & $\underline{\text { T-Stat }}$ \\
\hline INTERCEPT1 & $0.0794 *$ & 1.90 & 0.0460 & 1.36 & $0.0136 * * *$ & 2.84 & -0.0084 & -1.64 & $-1.4844 *$ & -1.75 & $-3.0921 * * *$ & -4.00 \\
\hline INTERCEPT2 & & & & & & & & & $1.5845 *$ & 1.86 & -0.0501 & -0.06 \\
\hline INTERCEPT3 & & & & & & & & & $4.9959 * * *$ & 5.86 & $3.2839 * * *$ & 4.24 \\
\hline \multirow[t]{2}{*}{ INTERCEPT4 } & & & & & & & & & $6.6164 * * *$ & 7.74 & $4.9029 * * *$ & 6.31 \\
\hline & & & & & \multicolumn{4}{|c|}{ Credit Scoring Variables } & & & & \\
\hline ADOPTED-SBCS 1 & 0.0049 & 0.72 & 0.0028 & 0.55 & $0.0169 * * *$ & 11.83 & $0.0179 * * *$ & 11.69 & -0.5414 & -2.96 & $-0.7920 * * *$ & -4.59 \\
\hline TIME-SINCE 1 & -0.0004 & -0.20 & 0.0000 & -0.01 & $0.0010 * * *$ & 5.89 & $0.0019 * * *$ & 10.79 & $-0.1950 * * *$ & -5.06 & $-0.0825 * *$ & -2.23 \\
\hline BOUGHT 1 & -0.0028 & -0.51 & -0.0001 & -0.04 & $-0.0150 * * *$ & -11.34 & $-0.0168 * * *$ & -11.72 & -0.0458 & -0.36 & -0.0078 & -0.07 \\
\hline SET-TERMS 1 & $0.0108 * *$ & 2.42 & 0.0070 & 1.93 & -0.0002 & -0.43 & $-0.0008 *$ & -1.76 & $2.0191 * * *$ & 29.08 & $1.8340 * * *$ & 27.67 \\
\hline \multirow[t]{2}{*}{ AUTO-APPROVE 1} & 0.0029 & 0.85 & 0.0008 & 0.26 & $-0.0010 * * *$ & -2.62 & $-0.0028 * * *$ & -7.62 & $1.5054 * * *$ & 19.23 & $1.2388 * * *$ & 17.19 \\
\hline & & & & & \multicolumn{4}{|c|}{ Imputed Effects of SBCS for "rules" banks } & & & & \\
\hline After 1 year & $0.0155 * *$ & 2.60 & $0.0104 * *$ & 2.15 & $0.0017 * * *$ & 2.88 & -0.0005 & -0.86 & $2.7423 * * *$ & 23.19 & $2.1905 * * *$ & 20.55 \\
\hline After 2 years & $0.0151 * * *$ & 3.00 & $0.0104 * *$ & 2.50 & $0.0027 * * *$ & 5.05 & $0.0014 * * *$ & 2.62 & $2.5473 * * *$ & 25.12 & $2.1080 * * *$ & 22.92 \\
\hline \multirow[t]{2}{*}{ After 3 years } & $0.0147 * * *$ & 3.12 & $0.0104 * *$ & 2.61 & $0.0037 * * *$ & 5.67 & $0.0033 * * *$ & 4.94 & $2.3523 * * *$ & 24.08 & $2.0255 * * *$ & 22.23 \\
\hline & & & & & \multicolumn{4}{|c|}{ Imputed Effects of SBCS for "discretion" banks } & & & & \\
\hline After 1 year & 0.0046 & 0.77 & 0.0028 & 0.63 & $0.0179 * * *$ & 12.40 & $0.0198 * * *$ & 12.74 & $-0.7364 * * *$ & -4.38 & $-0.8745 * * *$ & -5.60 \\
\hline After 2 years & 0.0042 & 0.75 & 0.0028 & 0.65 & $0.0189 * * *$ & 12.82 & $0.0217 * * *$ & 13.57 & $-0.9314 * * *$ & -5.80 & $-0.9570 * * *$ & -6.48 \\
\hline \multirow[t]{2}{*}{ After 3 years } & 0.0038 & 0.66 & 0.0027 & 0.58 & $0.0199 * * *$ & 13.06 & $0.0237 * * *$ & 14.26 & $-1.1264 * * *$ & -6.93 & $-1.0395 * * *$ & -7.01 \\
\hline & \multicolumn{8}{|c|}{ Bank and Market Variables } & & & & \\
\hline LN(GTA) & $-0.0047 * *$ & -2.52 & $-0.0039 * *$ & -2.26 & -0.0003 & -1.20 & 0.0002 & 0.68 & $-0.1579 * * *$ & -3.37 & $-0.0970 * *$ & -2.14 \\
\hline GTA $>10 B$ & 0.0016 & 0.43 & 0.0003 & 0.09 & $0.0039 * * *$ & 8.80 & $0.0044 * * *$ & 9.30 & $0.5155 * * *$ & 6.03 & $0.4659 * * *$ & 5.66 \\
\hline NPL & 0.2771 & 1.25 & 0.0977 & 0.54 & $0.2394 * * *$ & 8.89 & $0.3361 * * *$ & 11.16 & 2.7704 & 0.85 & $7.3648 * *$ & 2.30 \\
\hline ROE & $-0.0762 *$ & -1.93 & $-0.0642 *$ & -1.88 & $0.0462 * * *$ & 9.98 & $0.0722 * * *$ & 14.52 & $3.0414 * * *$ & 3.84 & $5.6284 * * *$ & 7.35 \\
\hline EQRAT & 0.0348 & 0.29 & 0.1239 & 1.30 & 0.0164 & 1.25 & $0.0460 * * *$ & 3.12 & $-9.7940 * * *$ & -3.85 & $-10.4002 * * *$ & -4.14 \\
\hline M-HERF & $0.0295 *$ & 1.87 & 0.0232 & 1.59 & $0.0109 * * *$ & 4.98 & $0.0283 * * *$ & 12.61 & & & & \\
\hline M-NPL & $-1.5982 * *$ & -2.27 & $-1.0072 *$ & -1.83 & $-0.1640 * *$ & -2.43 & $-0.1825 * *$ & -2.54 & & & & \\
\hline M-ROE & 0.1001 & 1.69 & 0.0919 & 1.62 & 0.0089 & 0.79 & 0.0068 & 0.55 & & & & \\
\hline \multirow[t]{2}{*}{ M-EQRAT } & $0.2804 * *$ & 2.40 & $0.2813 * *$ & 2.49 & $0.2060 * * *$ & 14.44 & $0.1673 * * *$ & 11.14 & & & & \\
\hline & \multicolumn{8}{|c|}{ Loan Contract Terms } & & & & \\
\hline (P)COLLATERAL 1 & 0.0068 & 0.70 & & & -0.0003 & -0.82 & & & $0.4577 * * *$ & 7.32 & & \\
\hline (P)COMMITMENT 1 & -0.0032 & -0.81 & & & $0.0067 * * *$ & 22.19 & & & $0.4669 * * *$ & 7.49 & & \\
\hline (P)DURATION 1 & 0.0002 & 0.08 & & & $-0.0032 * * *$ & -22.89 & & & -0.0115 & -0.45 & & \\
\hline (P)FLOATING RATE 1 & -0.0174 & -1.65 & & & $-0.0021 * * *$ & -3.57 & & & $-1.1238 * * *$ & -5.51 & & \\
\hline (P)TOTAL SIZE 1 & 0.0001 & 0.44 & & & $-0.0001 * * *$ & -28.49 & & & $0.0030 * * *$ & 3.30 & & \\
\hline Adjusted R-Squared & 0.5640 & & 0.5737 & & 0.2737 & & 0.1699 & & & & & \\
\hline $\mathrm{N}$ & 41 & & 41 & & 13,589 & & 13,589 & & 6,545 & & 6,454 & \\
\hline
\end{tabular}


Table 6. Credits 100K-250K: The overall effects of SBCS on small business loan ratios, loan premiums and loan risk ratings, 1997.

Regressions for SBL-RATIO 2, the ratio of small business loans between $\$ 100,000$ and $\$ 250,000$ to gross total assets, PREM 2, the premium over the Treasury rate of comparable repayment duration for loans between $\$ 100,000$ and \$250,000, and RISK-RATING 2, which equals 1 if the loan has "minimal" risk, 2 if the loan has "low" risk, 3 if the loanhas "moderate" risk, 4 if the loan has "acceptable" risk, and 5 if the loan is a special mention or classified asset. Data are taken for 1997. Number of observations vary across regressions. Where SBL-RATIO 1 is the dependent variable, the contract terms are bank averages. Where PREM 2 is the dependent variable, the regression includes Q2, Q3 and Q4, which indicate the quarter in which the loan was made, and $\mathrm{t}$-statistics are adjusted for heteroskedasticity and cross-correlations using the White correction. Where RISK-RATING 2 is the dependen variable, the regression includes Q3 and Q4, which indicate the quarter in which the loan was made. Significance at the $10 \%, 5 \%$ and $1 \%$ levels denoted by *,**, and *** respectively.

\begin{tabular}{|c|c|c|c|c|c|c|c|c|c|c|c|c|}
\hline \multirow{3}{*}{\begin{tabular}{|l} 
Dependent Variable: \\
$\underline{\text { Variable }}$
\end{tabular}} & \multicolumn{4}{|c|}{ SBL-RATIO 1 (Panel 1, OLS) } & \multicolumn{4}{|c|}{ PREM 1 (Panel 2, OLS) } & \multicolumn{4}{|c|}{ RISK-RATING 1 (Panel 3, Ordered Logit) } \\
\hline & \multicolumn{2}{|c|}{ Contract Terms } & \multicolumn{2}{|c|}{ No Contract Terms } & \multicolumn{2}{|c|}{ Contract Terms } & \multicolumn{2}{|c|}{ No Contract Terms } & \multicolumn{2}{|c|}{ Contract Terms } & \multicolumn{2}{|c|}{ No Contract Terms } \\
\hline & $\underline{\text { Coefficient }}$ & $\underline{\text { T-Stat }}$ & $\underline{\text { Coefficient }}$ & $\underline{\mathrm{T}-\mathrm{Stat}}$ & $\underline{\text { Coefficient }}$ & $\underline{T-S t a t}$ & $\underline{\text { Coefficient }}$ & $\underline{T-S t a t}$ & $\underline{\text { Coefficient }}$ & $\underline{\text { T-Stat }}$ & $\underline{\text { Coefficient }}$ & $\underline{\mathrm{T} \text {-Stat }}$ \\
\hline INTERCEPT 1 & $0.0688 * *$ & 2.53 & $0.0625 * *$ & 2.73 & $-0.0194 * * *$ & -3.62 & $-0.0235 * * *$ & -4.28 & $-5.5766 * * *$ & 6.07 & $-6.5028 * * *$ & 7.82 \\
\hline INTERCEPT2 & & & & & & & & & $-2.5620 * * *$ & 2.81 & $-3.5054 * * *$ & 4.26 \\
\hline INTERCEPT3 & & & & & & & & & -0.0801 & 0.09 & -1.0337 & 1.26 \\
\hline \multirow[t]{2}{*}{ INTERCEPT4 } & & & & & & & & & $1.6538 *$ & 1.80 & 0.7001 & 0.84 \\
\hline & & & & & \multicolumn{4}{|c|}{ Credit Scoring Variables } & & & & \\
\hline ADOPTED-SBCS 2 & -0.0008 & -0.44 & -0.0002 & -0.11 & $-0.0014 * * *$ & -4.17 & $-0.0019 * * *$ & -5.74 & $-0.1381 *$ & 1.71 & $-0.1906 * *$ & 2.49 \\
\hline & & & & & \multicolumn{4}{|c|}{ Bank and Market Variables } & & & & \\
\hline LN(GTA) & $-0.0039 * * *$ & -3.28 & $-0.0041 * * *$ & -3.56 & $0.0014 * * *$ & 6.13 & $0.0016 * * *$ & 6.69 & $0.2182 * * *$ & 4.55 & $0.2309 * * *$ & 5.05 \\
\hline GTA $>10 B$ & 0.0032 & 1.19 & 0.0043 & 1.55 & 0.0006 & 1.40 & 0.0006 & 1.29 & 0.1180 & 1.03 & 0.0987 & 0.88 \\
\hline NPL & -0.1219 & -0.93 & -0.0951 & -0.72 & $0.2426 * * *$ & 7.90 & $0.3782 * * *$ & 11.62 & -3.5525 & 0.73 & -3.6326 & 0.75 \\
\hline ROE & -0.0109 & -0.41 & -0.0069 & -0.25 & 0.0060 & 1.35 & 0.0045 & 0.94 & $1.5601 *$ & 1.78 & $1.7210 * *$ & 1.98 \\
\hline EQRAT & 0.0867 & 1.20 & 0.1149 & 1.63 & -0.0159 & -1.19 & 0.0000 & 0.00 & $-11.8885 * * *$ & 4.06 & $-10.6221 * * *$ & 3.71 \\
\hline M-HERF & -0.0037 & -0.31 & 0.0046 & 0.40 & $0.0084 * * *$ & 3.11 & $0.0156 * * *$ & 5.53 & & & & \\
\hline M-NPL & 0.0087 & 0.02 & 0.0631 & 0.16 & $-0.3485 * * *$ & -5.01 & $-0.5808 * * *$ & -8.12 & & & & \\
\hline M-ROE & -0.0164 & -0.37 & 0.0113 & 0.25 & $0.0635 * * *$ & 5.38 & $0.0986 * * *$ & 8.02 & & & & \\
\hline \multirow[t]{2}{*}{ M-EQRAT } & 0.0406 & 0.47 & 0.0224 & 0.25 & $0.1977 * * *$ & 14.29 & $0.1996 * * *$ & 13.69 & & & & \\
\hline & & & & & \multicolumn{4}{|c|}{ Loan Contract Terms } & & & & \\
\hline (P)COLLATERAL 2 & 0.0057 & 1.17 & & & $0.0023 * * *$ & 6.73 & & & 0.0027 & 0.03 & & \\
\hline (P)COMMITMENT 2 & -0.0056 & -1.57 & & & $0.0046 * * *$ & 12.42 & & & 0.1139 & 1.14 & & \\
\hline (P)DURATION 2 & -0.0029 & -1.65 & & & $-0.0026 * * *$ & -17.07 & & & $0.0688 * *$ & 2.03 & & \\
\hline (P)FLOATING RATE 2 & 0.0076 & 1.40 & & & $0.0037 * * *$ & 4.95 & & & $-0.9961 * * *$ & 3.51 & & \\
\hline (P)TOTAL SIZE 2 & 0.0000 & -0.35 & & & $0.0000 * * *$ & -2.93 & & & 0.0011 & 1.25 & & \\
\hline Adj. R-Squared & 0.4513 & & 0.3699 & & 0.2871 & & 0.1563 & & & & & \\
\hline $\mathrm{N}$ & 43 & & 43 & & 4,838 & & 4,838 & & 2,610 & & 2,610 & \\
\hline
\end{tabular}

